Sergio Zañartu, S.J.

Profesor de la Facultad de Teología

De la Pontificia Universidad Católica de Chile

\title{
El Dios razonable de la gran catequesis de Gregorio de Nisa
}

\section{INTRODUCCIÓN}

Este estudio solo se refiere a la Gran Catequesis, obra que muchos consideran que fue escrita entre el 381 y 386 . No pretende ser un trabajo exhaustivo sino una aproximación (1). Con todo, su metodología 'recopilatoria' llevará a necesarias repeticiones. Responde a la pregunta sobre lo que se dice de Dios en esta obra. Presenta un panorama general, en el que se destacan algunos énfasis (2). El más fundamental, en este tema, podría ser el de un Dios razonable. Gregorio dirige su discurso catequético a los que están al frente del misterio de la piedad (3). El modo de enseñanza debe adecuarse a los 'prejuicios' de los diferentes públicos. Porque no se cura con los mismos remedios el politeísmo del griego y la incredulidad del judío respecto al Dios unigénito (4). Dentro de ese público que no comparte nuestra fe, destacan, sobre todo en el comienzo de la obra, el judaizante y el que convive con el helenismo (5). Pero también enumera, dentro del catálogo de las herejías, al anomeo, maniqueo, a los marcionitas, valentinianos y basilidianos (6). Sabelio (junto

(1) Aunque muchas de las referencias al texto de Gregorio van a ser literales, no advertiré esto al lector, para no recargar este artículo y porque en todo el trabajo busco decir, lo más fielmente que pueda, lo del autor.

(2) Dado el copioso material que nos brinda esta obra de Gregorio, no haré referencias a otras obras de este autor, y solo muy escasas a bibliografía. Respecto a los influjos y fuentes, puede verse, $\mathrm{p}$. e., R. Winling (Grégoire de Nysse, Discours Catéchétique. Introduction, Traduction et Notes (SC 453), Paris 2000), pp. 113-125.

(3) Prol. p. 5, lin. 1s del texto de Mühlenberg, GNO III, 4, texto crítico que sigo en ese trabajo y según el cual cito. The present Or. Cat. is a manual for catechists who are engaged in the instruction of educated converts (J. H. Srawley, The Catechetical Oration of Gregory of Nyssa, Cambridge 1956, reprinted, ad 1. c.).

(4) Prol. 5, 17-6, 2.

(5) Vuelven a aparecer en $\mathrm{V}, 15,16-20$, como probablemente no replicando sobre la existencia de un Logos de Dios y de un Espíritu, pero rechazando por igual la economía humana del Logos de Dios; y en XIX, 52, 23-53, 1, como no convencidos de la $\pi \alpha \rho o v \sigma \iota \alpha$ de Dios, después de mostrar Gregorio cómo el cristianismo ha desplazado los cultos idolátricos y cómo el brillante culto judío ha desaparecido, lo que muestra la sabiduría del proceder divino. Pero en VIII, 35, 7s, refiere solo a los griegos, el proemio sobre el Logos creador de lo bueno.

(6) Prol. 5, 11-13. 
con el anomeo y maniqueo (7)) aparece un poco más adelante (8). Respecto al dogma trinitario, la concepción judaica (unidad de la naturaleza) y la del helenismo (solo la distinción de la hipóstasis) mutuamente se corrigen y de ambas, purificadas, podemos recibir lo útil. Porque la verdad avanza por en medio de ambas (9).

Frente a ellos, en esta obra profundamente inculturada en su época, el método de la exposición catequética será poner, según el 'prejuicio' y error de cada uno, ciertos principios y proposiciones razonables en los que se esté de acuerdo, y desde los cuales la verdad pueda ser desvelada por consecuencia lógica (10). De ahí la característica dialogal de esta exposición, donde a menudo encontramos preguntas y respuestas, y un cierto y mantenido tono apologético (11). Llama la atención la frecuente referencia a la $\alpha \kappa \operatorname{cov} \operatorname{\theta } \theta \alpha(12)$, y expresiones equivalentes en la argumentación (13). Por eso he titulado este trabajo: el Dios razonable. En sus argumentaciones se apoya bastante en las nociones comunes (14), p. e. en la perfección de Dios (15) o en que su actuar debe ser a la vez bondadoso, sabio, poderoso y justo (16); pero también en las Escrituras (17), p. e. en el Salmo 33, 6, para probar la Trinidad al judío (18). Así, tanto la razón común como las Escrituras muestran que

(7) Mención explícita de los maniqueos, que sostienen que el creador de la naturaleza humana es malo, hace de nuevo en VII, 26, 17, donde expone y refuta lo de ellos.

(8) Prol. 6, 5 s. El rechazo de que Dios se mezcle con un ser celestial en XXVII, 68, 11ss, lo que no serviría a los hombres, me recuerda el hombre divino, venido del cielo, de Apolinar, contra el que combate en su Antirrheticus. Se podrían hacer varias otras referencias, pero he preferido mantenerme en los que nombra explícitamente.

(9) Cf. III, 14, 1-13.

(10) Prol. 6, 7-13. Cf. p. e. XIX, 53, 5-7.

(11) Pretende hacer una 'apología' completa contra los que hablan mal de la economía divina (XXIV, $62,16 \mathrm{~s})$. Es muy argumentativo, con un matiz dialéctico. A veces da una respuesta simple a adversarios que no opongan demasiada resistencia (XXXIII, 82, 22 s). Cf. VI, 23, 12s; XVII, 50, 1s; XVIII, 50, 20-23, etc. Algunas veces achacará faltas de lógica a los adversarios en un supuesto diálogo, p. e. XXXIII, 82, 9ss. Afirma Srawley (op. cit., xii): While it abounds in philosophic thought, the aim throughout is practical. The object of the writer is to enable the catechist to remove objections and to win conviction. When he calls to his aid the speculations of philosophers, he does so, not so much because he regards them as the necessary form of truth, as because they provide a common ground for argument.

(12) Ocho veces, según el texto de Srawley (cf. TLG), excluidos los textos XVI, 48, 10; 49, 11 y

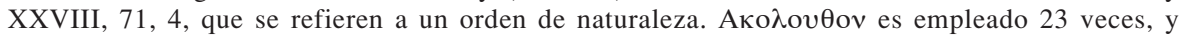
$\alpha \kappa o \lambda o v \theta \omega s$ 2. Cf. XIX, 53, 6; XXIII, 58, 5; XXVII, 70, 7. Puede verse, J. Daniélou, Akolouthia chez Grégoire de Nysse, Rev SR 27 (1953) 217-249; H. Drobner, Fuentes y métodos filosóficos de Gregorio de Nisa, Teología y Vida 43 (2002) 205-215. En adelante, cuando me refiera a número de veces de un vocablo, normalmente será tomando como base el texto de Srawley.

(13) Así, entre otros términos, usa: $\varepsilon v \lambda \circ \gamma \circ \varsigma, \alpha \nu \alpha \gamma \kappa \eta$ y $\alpha v \alpha \gamma \kappa \alpha \iota \varsigma, \delta \varepsilon \iota, \chi \rho \eta, \alpha \pi \circ \delta \varepsilon \xi \xi \varsigma$, y formas similares o derivadas; futuros pasivos como $\pi \rho 0 \sigma \alpha \chi \theta \eta \sigma \varepsilon \tau \alpha \iota$, algunos tipos de conjunciones como las causales. Habla a menudo de $\alpha \iota \tau \iota \alpha$ (15 veces, además del uso de $\alpha \iota \tau \iota \circ \varsigma)$, aunque no siempre se refiera a una causa (p. e. XXX, 74, 16). El adverbio $\pi \alpha \nu \tau \omega \varsigma$ con frecuencia es usado

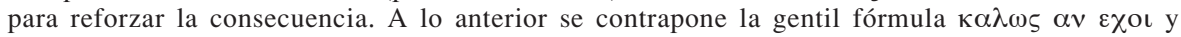
variantes (9 veces) y el a veces uso de la primera persona del singular.

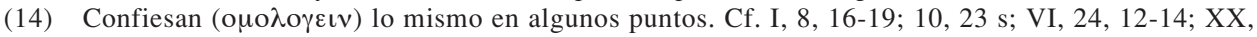

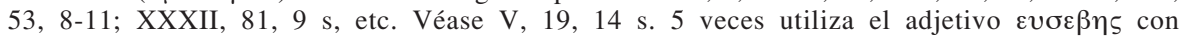
referencia a algo compartido o que debe ser compartido por todos.

(15) Prol. 7, 1s, etc.

(16) Cf. Prol. 8, 3-6; XX, 53, 8-11, etc.

(17) Afirma J. Barbel (Gregor von Nyssa, Die grosse katechetische Rede (Bibliothek der griechischen Literatur, 1), Stuttgat 1971, p. 28): An ausdrücklichen Schriftzitaten ist das Buch erstaunlich arm.

(18) IV. Las Escrituras inspiradas por Dios muestran más claramente la existencia del Logos y del Espíritu de Dios (IV, 14, 17-20). 
es imposible entrar al coro divino sin una total purificación (19). Respecto al gran misterio de la economía según el hombre, discutirá largamente sobre lo que es digno o indigno de Dios (20). A partir del final del número XXXII (82, 1), añade la economía del bautismo, etc., como parte de las enseñanzas mistéricas, y parece dirigirse a un público más cristiano.

Los cristianos muestran una 'filosofía' excelsa (21), especialmente en su culto y conducta. Pero la razón se ejercita respecto a un misterio (22), que la supera (23). El griego y el judío pueden llegar a no impugnar la existencia de un Logos y de un Espíritu de Dios, pero les parecerá increíble e indigno (inconveniente) (24) de Dios la economía del Logos de Dios según el hombre (25). Y tratado el problema del mal, agrega que quizás hasta aquí esté de acuerdo el contrincante al ver la consecuencia lógica en la que no hay nada indigno de Dios (26). Pero no se comportará igualmente con lo que sigue (nacimiento..., cruz, muerte y sepultura), por lo que se refuerza sobre todo el misterio de la verdad (27). Pero, replica entre otras cosas Gregorio, si ignoramos la forma de unión del alma con la carne, ¿cómo vamos a ser capaces de comprender el modo de la mezcla de la divinidad con la humanidad? Es superior al curso de nuestros razonamientos (28). Al conocimiento de Dios me referiré después más explícitamente.

(19) XXXVI, 92, 8-11. El griego se apoya en las nociones comunes y el judío en las Escrituras (V, 15, $16 \mathrm{~s})$.

(20) Así, de las 11 veces en que usa $\theta \varepsilon$ o $\rho \varepsilon \pi \eta \varsigma$ en la obra, ocho están en esta sección (no contando como de ella V, 17, 24); y de las 8 veces que usa $\alpha \pi \rho \varepsilon \pi \eta 5$, siete (no contando como de ella V, $15,20)$. Igualmente, en esta sección, las 10 veces que utiliza el verbo $\pi \rho \varepsilon \pi \varepsilon \iota v$, y la única con

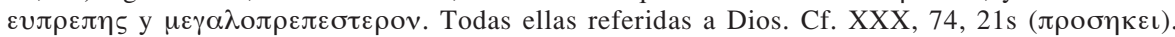
Mostrará también que el misterio no tiene nada fuera de lo verosímil ( $\varepsilon\llcorner\kappa o \varsigma)$ (XXIV, 63, 11s; XXXII, 78, 17s). Véase XXV, 63, 18 s; XXVII, 70, 18 s; XXXII, 81, 10; XXXVII, 96, 2 s, etc.

(21) XVIII, 51, 18.

(22) La palabra $\mu v \sigma \tau \eta \rho ı v$ aparece 31 veces. Del profundo e inexpresable misterio trinitario, se puede alcanzar cierta inteligencia (III, 13, 12-17; cf. XXXII, 77, 21-24; 80, 18-21). También Gregorio

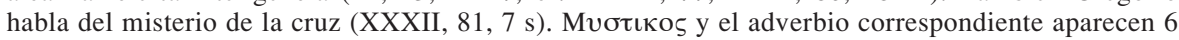
veces, 5 de las cuales en el agregado final. Cf. además XXXII, 80, 19; XXXIII, 82, 21; XXXV, 91, 10; 92, 7; XL, 103, 7. Sobre sentido del substantivo puede verse, p. e. Barbel, op. cit., Kom., 3.

(23) De ahí los ejemplos comprensibles (cf. p. e. X, 38, 20-23; XXX, 74, 7 s).

(24) Por razones de resonancia de la lengua castellana, traduciré normalmente $\pi \rho \varepsilon \pi \eta \varsigma$ por digno, y $\alpha \pi \rho \varepsilon \pi \eta \varsigma$ por indigno.

(25) V, 15, 16-20. Cf. XXV, 64, 1s; XXVI, 67, 14 s; XXVIII, 71, 9. Véase IX, 36, 17-37, 5.

(26) Todo pensamiento elevado y piadoso se aplica a Dios, relacionándose el uno con el otro mediante la consecuencia lógica (XXIV, 62, 21-23). Creo que esta relación mutua se puede aplicar a la conjunción de bondad, sabiduría, poder y justicia en la acción divina, en la que tanto insiste Gregorio.

(27) IX, 36, 17-37, 2.

(28) XI, 39, 11-40, 6. La diferencia de naturaleza es $\mu \varepsilon \gamma \alpha \lambda$ o $\rho \varepsilon \pi \varepsilon \sigma \tau \varepsilon \rho o v$. Igualmente, admitiendo el ser creados, dejamos a un lado el modo (el de dónde y el cómo) de la constitución del universo como del todo indecible e inexplicable. Usa también respecto a lo divino y al misterio, los

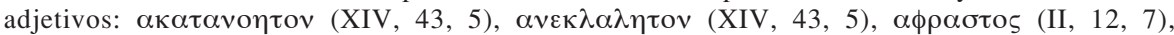

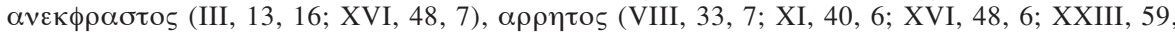

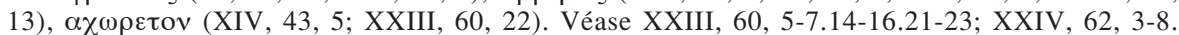
Está por encima de toda $\delta o \xi \alpha(X I V, 43,6)$. Véase VIII, 33, 20-34, 2: la descripción de los bienes que esperamos como de los dolores que purifican el alma, que son indecibles ( $\alpha \rho \rho \eta \tau$, $\alpha v \varepsilon \kappa \phi \rho \alpha \sigma \tau o l, \alpha \phi \rho \alpha \sigma \tau o v)$, está por sobre la capacidad de las palabras y la conjetura del pensamiento. Cf. XL, 105, 11-106, 10; 106, 14 s. 
Lo que ahora solo se ve por la fe, se revelará en los siglos venideros (29). La fe cristiana es gracia de Dios (30). Si la fe no ha llegado a todos, no es porque Dios no haya llamado a todos por igual, sino porque recibir la fe depende del libre albedrío del hombre (31). Gregorio, con sus argumentos, pretende conducir hacia esta fe (32) o que nada la estorbe (33). Su catequesis es una defensa de la fe (34).

\section{EL LOGOS Y LA TRINIDAD}

Partiendo de las sabias y hábiles disposiciones del cosmos, confesamos que existe un cierto poder superior ( perfecta en todo lo que es digno de Dios. Es una sola, porque en la perfección no hay nada que dé para distinguir un dios de otro, como en la hipótesis politeísta. La identidad en todo (no diferencia) conduce, pues, a la fe en el uno (36). Pero hay una distinción ( $\iota \alpha \kappa \rho \iota \sigma \iota v)$ de hipóstasis en la unidad de naturaleza. Combatiendo a los griegos, con una hábil diferencia $\left(\delta \iota \alpha \sigma \tau \sigma \lambda \eta_{\mathrm{\iota}} \tau \varepsilon \chi \nu \iota \kappa \eta_{\mathrm{\iota}}\right)$ evitamos caer en el error del judaísmo. Nadie concibe la divinidad sin logos (37). Pero este Logos no es semejan-

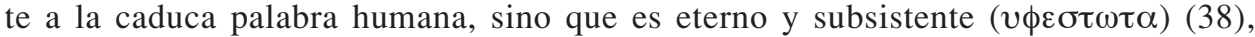
como corresponde a la naturaleza de Dios (39). Y este subsistir (40) como algo incorporal e inteligente, implica absolutamente el vivir. De lo contrario, del todo no

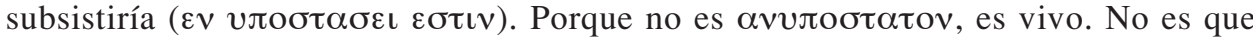
participe de la vida, sino que, dada su naturaleza simple, es $\alpha v \tau o \zeta \omega \eta$. Y si vive,

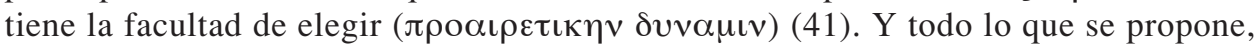

(29) XVII, 50, 13-15. Cf. XVII, 50, 9-17. Ahora, con raciocinios, en cuanto es posible, busca solución a lo planteado.

(30) Cf. XXX, 74, 15-21; 74, 22-75, 1, etc.

(31) XXX, 75, 5-XXXI, 77, 6. Véase XXXVI, 92, 21s.

(32) P. e. V 15, 21s; Prol. 8, 8 s; XIII, 42, 11-13. En XI, 40, 3 s, hace referencia indirecta a temas que

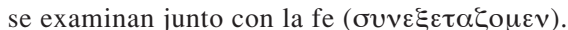

(33) XV, 44, 16-20; XII, 41, 7s. Así, examina la 'fisiología' del cuerpo para que nuestra fe, mirando a la consecuencia lógica, no tenga dudas respecto a la Eucaristía (XXXVII, 94, 16-20). Según el objetante, el descenso de la divinidad a lo más bajo deja a la fe dudosa (XIV, 43, 3 s; cf. IX, 37, 3-5).

(34) Véase, p. e. XV, 45, 5-8; XXIV, 62, 15-17 ( $\alpha \pi \mathrm{o} \lambda \mathrm{o} \gamma \iota \alpha \nu)$.

(35) Cf. también V, 15, 22-16, 5; XXIV, 61, 22-25: contemplando el universo y examinando las economías cósmicas y los beneficios divinos en nuestra vida. Véase XII, 40, 8-15.

(36) Prol. 6, 14- 8, 9.

(37) Se apoya en una cultura típica de la época. Destaco lo que dice R. J. Kees: Es sieht so aus, als ob Gregor die erste Hypostase der Trinität mit der Gottheit selbst identifiziert, Wesen und erste Person sind in der Trinitätslehre der Or Cat scheinbar identisch. Gregor erweist nicht, dass die göttliche Natur als Vater, Sohn und Geist existiert, sondern er zeigt, dass Gott ein Logos und ein Pneuma hat (Die Lehre von der Oikonomia Gottes in de Oratio Catechetica Gregors von Nyssa (Supplements to Vigiliae Christianae, 30), ed. Brill 1995, p. 101). Yo agregaría que este es su camino razonable. Y desde ahí pasará a la economía.

(38) Esta expresión, que corresponde a la naturaleza divina incorruptible y siempre $\varepsilon \sigma \tau \omega \sigma \alpha$, es traducida por A. Velasco (en M. Naldini, Gregorio de Nisa, La Gran Catequesis (Biblioteca de Patrística, 9), $2^{\text {a }}$ ed., Madrid 1994, ed. Ciudad Nueva), como 'substancial'. De hecho, va contrapuesta a nuestra palabra caduca, $\alpha v v \pi 0 \sigma \tau \alpha \tau o \varsigma, \alpha \pi \alpha \gamma \eta \varsigma$, que se desplaza hacia la inexistencia. El Logos

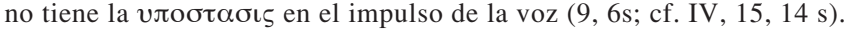

(39) I, 8, 10-9, 11 .

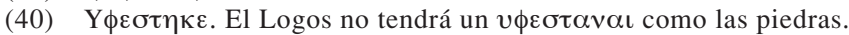

(41) R. Winling traduce en Sources Chrétiennes por 'faculté de vouloir', y por 'volonté' el $\pi \rho 0 \alpha \iota-$ povpevou de 10,21 , etc. 
lo puede hacer, como corresponde al concepto de lo divino. Y todo lo que es bueno, eso es lo que quiere y opera. El universo, que es bueno, es obra de este Logos viviente y subsistente ( $v \phi \varepsilon \sigma \tau \omega \tau(\varsigma)$, porque es Logos de Dios. Logos con libre

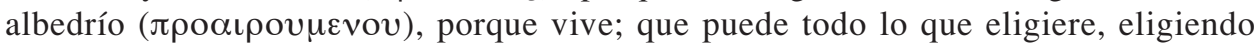
del todo lo bueno, sabio y mejor (42).

Pero el Logos es otro, respecto a Aquel de quien es Logos. Hay que distinguir entre el Logos y el de dónde es, para no caer en los conceptos judaicos. Por eso, confesamos un Logos de Dios viviente, operante y creador, lo que no acepta el judío, como tampoco que el mismo Logos no difiera, por naturaleza, de Aquel de quien es (43). Nuestra palabra ni es del todo lo mismo ni es del todo otro respecto al vous. Es un algo otro, viniendo del vous, pero no lo es en cuanto lo manifiesta. Es decir, es uno con el vous según la naturaleza, otro en cuanto sujeto $\left(\tau \omega_{\text {}}\right.$

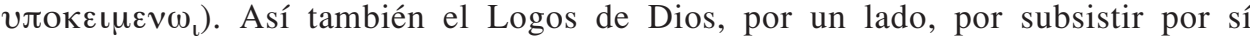

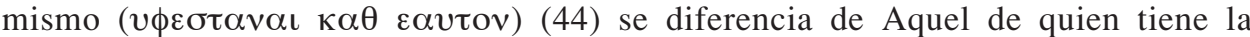

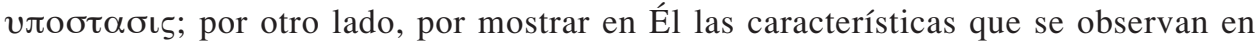
Dios, es el mismo que Este según la naturaleza. Ya sea la bondad, ya el poder, sabiduría, ser eternamente, no admitir la maldad, muerte y corrupción, ya sea la perfección en todo, ya cualquier otro atributo que se pudiera pensar como signo distintivo de la idea del Padre. Por esos mismos signos encontraremos al Logos

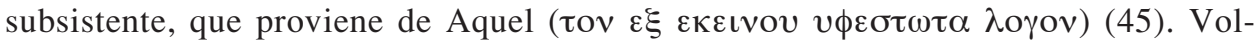
viendo al texto según el cual el Logos es otro en cuanto sujeto ( $\varepsilon \tau \varepsilon \rho o v \tau \omega_{\mathrm{t}}$

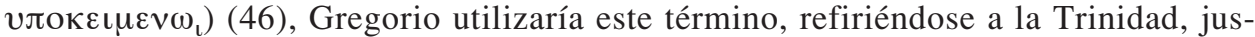

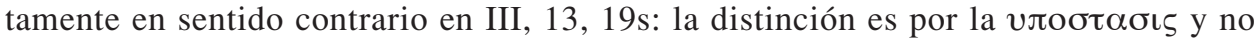

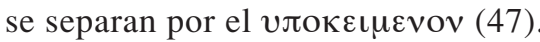

Así como conocimos anagógicamente al Logos partiendo de lo nuestro, así seremos acercados a la noción del Espíritu mediante ciertas sombras e imitaciones en nuestra naturaleza, de la potencia inefable. Respiramos el aire $(\pi v \varepsilon v \mu \alpha)$, y este puede convertirse en voz que manifiesta en sí misma el poder de la palabra. Y como el Logos de Dios no es inferior al nuestro, hay que creerlo con Espíritu. Pero un Espíritu digno de Dios, como en el caso del Logos, a quien acompaña y cuya actividad manifiesta. Es

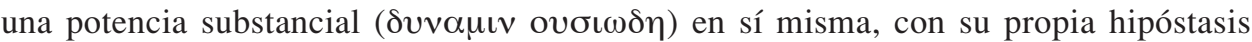

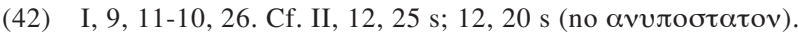

(43) I, 10, 26-11, 12.

(44) Este subsistir por sí mismo y no en otro ( $\varepsilon v v \pi o \sigma \tau \alpha \tau o v)$, caracterizará el concepto de $v \pi 0 \sigma \tau \alpha \sigma \iota \varsigma$ aplicado a la discusión cristológica en el neocalcedonismo. Cf. S Zañartu, Historia del dogma de la Encarnación desde el siglo V al VII, Santiago 1994, 148 pp., ed. Univ. Catol. de Chile, pp. $72-$ 78.; Idem, Reflexiones sobre la fórmula dogmática del concilio de Calcedonia, Teología y Vida 39(1998)155-184, pp. 173-179.

(45) I, 11, 12-12, 3

(46) I, 11, $17 \mathrm{~s}$.

(47) Este término también lo utiliza dos veces respecto a la encarnación al ilustrar, comparando con la llama y la materia ( $(X, 38,24 ; 39,5)$. Ambos conforman una unidad inseparable, pero distinguible. También el alma se despliega a voluntad por toda la creación, y no es circunscrita por el cuerpo. En los otros casos en que utiliza el término, este está más bien referido a lo que está abajo (XXXII, 80, 23), a lo subyacente (VIII, 33, 14; cf. XXXIII, 83, 16 referido al semen, que por el poder de Dios se convierte en hombre), llegando solo en XVI, 46, 10 (cf. Prol. 7, 14) a significar más bien el sujeto. Por tanto, su uso en I, 11, 17s como sujeto en la Trinidad, es más bien excepcional. Cf. Winling, op. cit., p. 150, n. $1 ; 298$, n. 1 . La naturaleza divina es $v \pi \varepsilon \rho \kappa \varepsilon \iota \mu \varepsilon v \eta$ respecto al cosmos (5 veces). 
( $\left.\varepsilon \vee \iota \delta \iota \alpha \zeta o v \sigma \eta_{\iota} v \pi 0 \sigma \tau \alpha \sigma \varepsilon \iota\right)$, inseparable de Dios en quien está y del Logos a quien

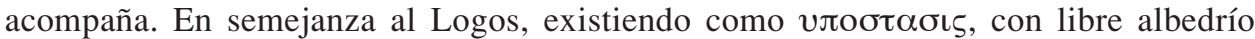

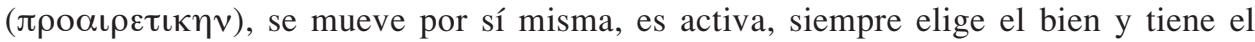
poder correspondiente para realizar su propósito según su voluntad (48).

En esta primera parte de su obra, Gregorio, después de presentar la existencia del Dios uno, de su Logos y de su Espíritu, pasa a considerar la profundidad indecible de este misterio (núm. III y IV). Es numerable y escapa a la numeración; se lo ve con distinciones $\left(\delta\left\llcorner\eta_{\iota} \rho \eta \mu \varepsilon v \omega \varsigma\right)\right.$ y se lo concibe como unidad ( $\left.\varepsilon \nu \mu o v \alpha \delta \iota\right)$; se lo ha

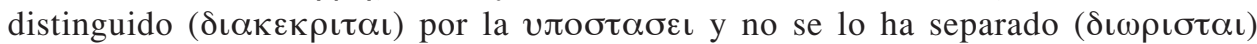
por el $v \pi о \kappa \varepsilon \iota \mu \varepsilon v \omega_{\imath}$. Por la $v \pi о \sigma \tau \alpha \sigma \iota \varsigma$ es algo otro el Espíritu, y otro el Logos, y otro, a su vez, aquel de quien es el Logos y el Espíritu. Pero cuando hayas compren-

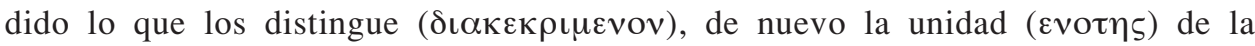
naturaleza no admite partición ( $\delta \iota \alpha \mu \varepsilon \rho \varsigma \mu o v)$, de forma que el poder de la monar-

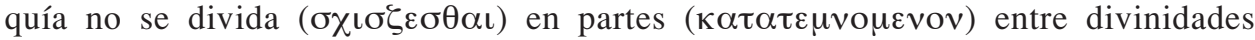

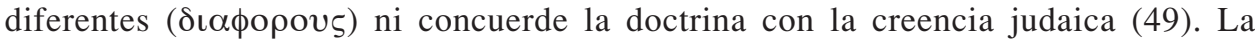
creencia judía es vencida por la aceptación del Logos y la fe en el Espíritu, y el error politeísta de los helenizantes se desvanece, anulando la unidad ( $\varepsilon v o \tau \eta \tau o \varsigma$ ) la fanta-

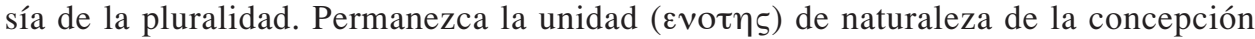
judaica, y del helenismo solo la distinción ( El número de la Tríada (51) es como una terapia para los que yerran respecto al uno ( $\tau$ o $\varepsilon v$ ), y la doctrina de la unidad para los que se dispersan en la pluralidad (52).

Finalmente en esta parte, Gregorio prueba para el judío, por las Escrituras inspiradas por Dios, la existencia del Logos y del Espíritu, potencias substanciales

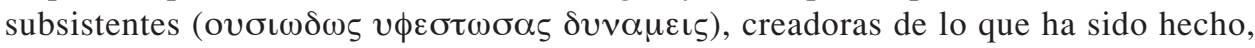
y que abrazan a los seres. David dice (53): "Con el Logos del Señor los cielos fueron consolidados, y con el Espíritu de su boca todo su ejército". No es con nuestra palabra humana ni con nuestro aliento. Nuestras palabras y el soplo que sale

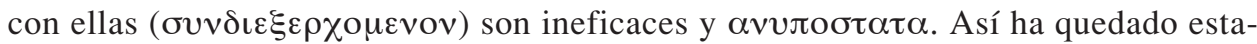

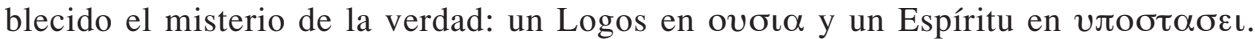

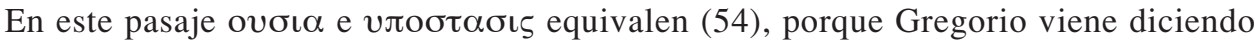
lo común al Logos y al Espíritu, y ambos se contraponen a nuestras palabras y soplo $\alpha v v \pi$ o $\tau \alpha \tau \alpha$. Habría que traducirlos por 'substancial' (55). Esto es distinto del uso

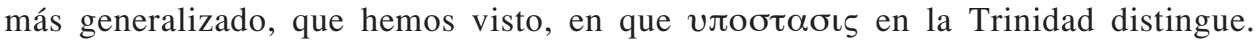

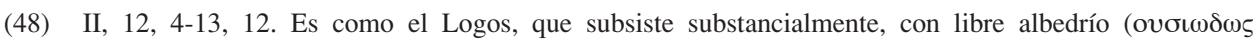

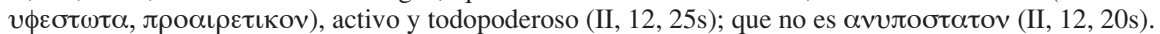

(49) Así la verdad avanza por en medio de ambas concepciones venciéndolas y aceptando lo útil de ellas. Este ir y venir entre el polo de la unidad y el de la distinción me recuerda los discursos teológicos de Gregorio de Nacianzo (cf. S. Zañartu, Presentación de algunos aspectos de la Trinidad en los discursos teológicos de Gregorio de Nacianzo, Teología y Vida 43 (2002) 436-464).

(50) Mutuamente se corrigen los pensamientos impíos.

(51) Única vez que este vocablo aparece en esta sección. En la sección final sobre la fe (nacimiento del bautismo), lo encontraremos otras 4 veces (núm. 39).

(52) III, 13, 12-14, 13

(53) Sal 32, 6.

(54) También equivalían en el canon del concilio de Nicea, pero ahí para expresar la unidad de substancia; aquí, en cambio, para expresar la distinción en Dios. Cf. DH 126.

(55) Winling traduce: "d'un Logos substantiel et d'un Pneuma ayant la subsistence". En la introducción (Ib., p. 47s) quiere interpretar ambos por 'subsistente efectivamente'. Cf. I, 9, 6s. 
Concluyendo esta sección, Gregorio ha mostrado la existencia del Logos y del Espíritu al griego mediante las nociones comunes, y al judío mediante las Escrituras. Quizás estos no repliquen, pero lo que rechazarán es la economía humana del Logos de Dios como indigna de Dios (56).

He dejado para ahora el comentario a I, 11, 1-6, respecto a la relación entre el Logos y el Padre. Después de decir que el Logos es otro respecto a aquel de quien es Logos, añade que de alguna forma es un $\pi \rho \circ \varsigma \tau \iota$ (relación), porque es del todo

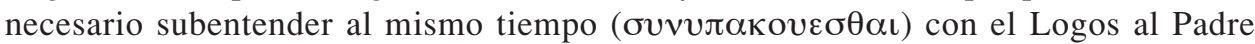
del Logos. Pues no sería logos si no es logos de alguien. Debe distinguirse entre el Logos y el de dónde es, por lo relativo de la significación del término $\left(\tau \omega_{\iota} \sigma \chi \varepsilon \tau \iota \kappa \omega_{\mathrm{\iota}}\right.$

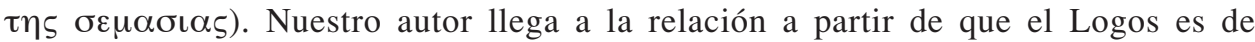
alguien, y ese alguien, a quien implica, lo aclara diciendo que es el Padre del Logos (57). Poco más adelante (58), para probar que el Logos y aquel de quien tiene la

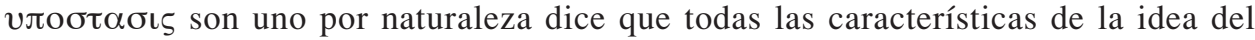
Padre, son también las del Logos.

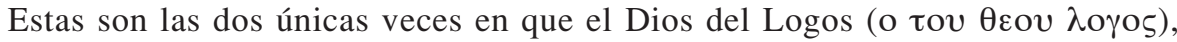

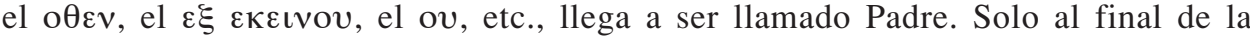
obra, en el agregado más práctico, sobre las enseñanzas mistéricas, volverá a hablar del Padre y no directamente en relación al Hijo, sino para decir que el bautizado es engendrado por parejo por los tres; por el Padre y por el Hijo y por el Espíritu Santo. Y para probar que es engendrado por el Padre, dice que este es Padre de todos (59). Para este nacimiento se tiene que elegir por padre (6056) a la Trinidad increada. Y si el cristiano al bautizarse cree que el Hijo y el Espíritu están fuera de la naturaleza del Dios primero, verdadero y bueno, es decir del Padre, rechazando la fe en la naturaleza supereminente, permanecerá sometido al yugo de las creaturas (61). Y el correlativo nombre de hijo, que corresponda al Logos (62), no aparece más, aunque señala en Prol. 6, 2 la incredulidad del judío respecto al Dios unigénito

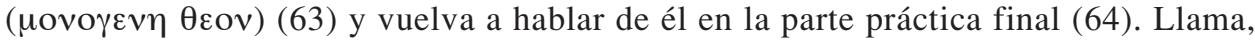
pues, la atención el arrinconamiento del nombre de Padre en la Trinidad. Es que se ha centrado en el Logos en un discurso que titulamos 'racional' sobre Dios. En la parte final se menciona también a la Tríada (usando ese vocablo) en XXXIX, 99, 15s.; 100, 3.5.18. Se trata de ser engendrado en ella, de confesar la santa Trinidad increada (sin naturaleza creada) para entrar en el bautismo, en la vida inmutable y tomarla así como principio fontal $(\alpha \rho \chi \eta \gamma o v)$ de la propia vida. Porque en el evange-

(56) IV, 14, 14-V, 15, 20

(57) Tomás también a partir del Verbo deducirá al Hijo y al Padre: el proceder como Verbo es una generación.

(58) I, 12, 1-3.

(59) XXXIX, 99, 13-19. Cf. Ef 4, 6. Para probar que es engendrado por el Espíritu trae lo del Evangelio: lo que es nacido del Espíritu, es espíritu (Jn 3, 6). Y respecto al Hijo, Pablo engendra en Cristo (1Co 4, 15).

(60) Cf. también XXXIX, 99, 3 s.

(61) XXXIX, 100, 16-101, 6. Parece tener en mente el arrianismo, sobre todo Eunomio. Véase XXXIX, 99, 22-100, 7. Según V, 20, 9 s, la maldad no puede titular a Dios: Creador y Padre

(62) En XL, 104, 17, se refiere al cristiano que llega a ser hijo de Dios. Cf. también XL 105, 7.

(63) Expresión muy usada en el Contra Eunomium.

(64) Si el hombre considera creado al Dios unigénito y al Espíritu, es vana su esperanza en un cambio a algo superior en el nacimiento de arriba (XXXIX, 101, 16-19). 


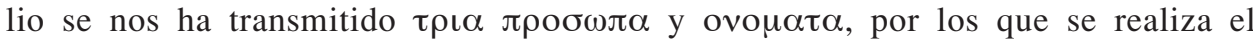
nacimiento de los creyentes (65). Esta es la única vez en que aparece $\pi \rho 0 \sigma \omega \pi$ y y ovo $\mu \alpha$ referidos al misterio trinitario.

Pero hay más todavía respecto a la racionalidad antes dicha. De los tres (Padre, Hijo y Espíritu) no se vuelve a hablar en forma conjunta. En ese sentido la Trinidad está del todo confinada a la primera parte $(\mathrm{I}, 8,10-\mathrm{V}, 15,18)$ y a la última (XXXIX, 99, 13-102, 3), en total unas 11 páginas de aproximadamente 100 que tiene el texto de Mühlenberg, las que hemos visto hasta ahora. Así, por ejemplo, fuera de lo anterior, encontramos menciones del Espíritu solo en XXXII, 81, 16s y XL, 103, 9s. En la primera, hablando de Cristo que después de la resurrección se manifestó a sus discípulos sin entrar por las puertas, dice de paso Gregorio, que los fortificó insuflándoles ( $\pi \rho \circ \sigma \phi v \sigma \eta \sigma \varepsilon \iota)$ el Espíritu. En la segunda se atreve a decir que, para el que no cambia su vida reflejando los rasgos del actuar de Dios, el agua del bautismo es simplemente agua, no manifestándose de ninguna manera el don del Espíritu Santo en lo que se realiza.

Fijémonos ahora en el resto del uso, en esta obra, del vocablo Logos cuando significa la respectiva $v \pi \delta \sigma \tau \alpha \sigma \iota \varsigma$ trinitaria. Fuera de la exposición trinitaria del comienzo, ya vista, el vocablo solo es usado 5 veces en la página que sigue (V, 16, 5-17, 7), destacando magníficamente al Logos de Dios, creador del mundo (66), y del hombre en todo bien, por amor, para que este participara de lo divino (67); 2 veces en diez líneas de referencia y resumen a lo dicho en el proemio a los griegos, para afirmar que el Logos creó al hombre con óptimos bienes, a semejanza de Dios (VIII, 35, 6-16 (68)); y 11 veces en una página del complemento mistérico, a propósito de la transformación del pan en el cuerpo del Logos (XXXVII, 96, 6-97, 12)

(65) XXXIX, 99, $13 \mathrm{~s}$.

(66) Cf. I, 10, 19-26.

(67) Después de afirmar que todo ha sido creado por la razón y sabiduría del que constituyó el universo y que así es gobernado, añade que el Logos de Dios, como se demostró antes, no es una voz ni la posesión de una cierta ciencia o sabiduría, sino una potencia subsistente que elige $(\tau \iota \varsigma$

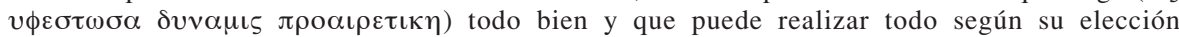
( $\pi \rho \circ \propto \iota \varepsilon \sigma \iota v)$. Siendo el cosmos bueno, su causa es una potencia que dispone de los bienes y los

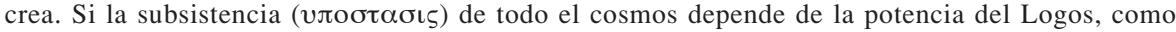
demostró la consecuencia lógica, es del todo necesario pensar que las partes del cosmos no tienen alguna otra causa de su organización que el mismo Logos, del que todas las cosas han tenido el acceso al existir. No discutirá sobre el nombre: Logos, sabiduría, potencia, Dios u otro nombre sublime y venerable (cf. también XXXII, 80, 8-11). La potencia eterna de Dios, la creadora de los seres, la que concibe lo que no existe, la que mantiene unido lo que ha llegado a ser, la que prevee lo por venir. Este Logos Dios, sabiduría, potencia, ha sido mostrado, según la consecuencia lógica, como creador de la naturaleza humana, llevado a la formación del hombre, no por

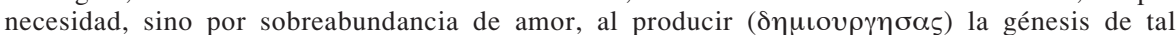
viviente. Era necesario que su luz, su gloria, su bondad y los otros atributos de su naturaleza divina, no permanecieran inoperantes, al no tener quien participara y gozara de ellos.

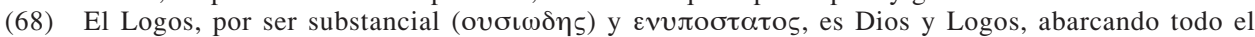
poder creador; mejor aún, al ser potencia por sí mismo ( $\alpha v \tau o \delta v \mu \alpha v \iota \varsigma)$ y tener un impulso hacia todo bien y al realizar todo lo que quiere, tiene un poder que coincide con su querer. $\mathrm{Y}$ es voluntad y obra suya la vida de los seres. Y también por Él, el hombre fue conducido a la vida, adornado con todo lo óptimo, a semejanza de Dios. Esto lo dice Gregorio a propósito de que Dios no es el autor de los males en que se ve sumido el hombre. Ahora afirma que el hombre fue creado a semejanza de Dios; antes había dicho que el Logos de Dios no era semejante al nuestro caduco, aunque anagógicamente había partido del nuestro. 
(69). En este último párrafo, nos habla del Logos, que es Dios y Logos (70), que se mezcló con la naturaleza humana; del cuerpo del Logos, en el que inhabitó, al que santificó, transformó y elevó a dignidad divina. Así también santifica y transforma el pan. Por tanto y a fin de cuentas, en toda la parte central de este escrito sobre la economía del Logos de Dios según el hombre (71), el término Logos apenas es usado. Solo al comienzo, a propósito de la creación del mundo bueno y del hombre y después en un brevísima referencia y resumen de lo anterior. Es decir, la encarnación, que obviamente es la del Logos, suele ser dicha con términos más generales, como los de Dios y hombre, sin la riqueza trinitaria del Logos de Dios, como tampoco del Hijo del Padre, del enviado, etc. Creo, de nuevo, que esto se debe principalmente y en último término a que está centrado en el Dios racional.

En conclusión, Gregorio defiende claramente tanto la distinción de las

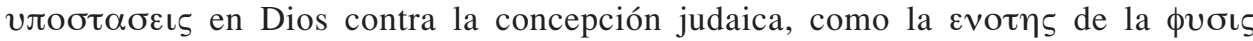

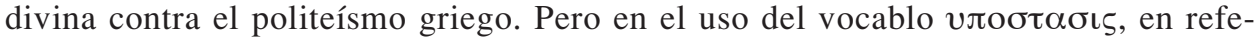
rencia a la Trinidad, conserva alguna ambigüedad (72). El vocablo $\pi \rho 0 \sigma \omega \pi$ ov solo lo utiliza una vez. En la distinción, atribuye al Logos y al Espíritu un carácter substancial, diferente del caduco de la palabra y hálito del hombre. Son potencias creadoras libres (73). El Logos, creador del hombre y del mundo por amor, solo tiende a lo bueno y es omnipotente para realizarlo. Los principales referentes explícitos de la defensa del Dios uno y trino son el helenismo y el judaísmo, lo que no excluye las otras herejías que nuestro autor menciona. Su raciocinio se apoya, además del texto bíblico para el judío, en que todos aceptan la existencia de un Logos de Dios, y este debe tener Espíritu como el hombre tiene hálito. Pero tanto el Logos como el Pneuma son divinos, diferentes de lo efímero humano. Recordemos que ya el A. T. habla de un Espíritu de Yahweh y de su Palabra y Sabiduría. Gregorio es un

(69) El Logos de Dios, el que es a la vez Dios y Logos, se mezcló a la naturaleza humana y llegó a ser

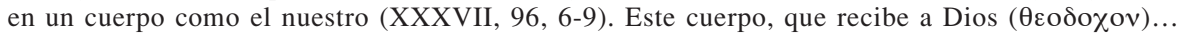
por la inhabitación del Logos de Dios, fue transformado en dignidad divina. Ahora, el pan, santificado por el Logos de Dios se transforma en cuerpo del Logos de Dios. Y aquel cuerpo era pan en potencia y fue santificado por la habitación del Logos, quien puso su tienda en la carne. Por tanto, el pan transformado en aquel cuerpo se cambió en potencia divina. De la misma manera, también ahora sucede igual. Pues allá la gracia del Logos santificaba el cuerpo, cuya consistencia venía del pan, siendo él mismo, en cierta manera, también pan. Aquí, de la misma manera, el pan, como dice el Apóstol, es santificado por el Logos de Dios y la plegaria. No es que él llegue a ser, por ser comido, el cuerpo del Logos, sino que es transformado inmediatamente por el Logos en cuerpo, como fue dicho por el Logos: esto es mi cuerpo (XXXVII, 96, 16-97, 12).

Dicho de otra forma, Gregorio parte de la premisa que todo cuerpo humano debe su consistencia al pan que come, y por tanto, en cierto sentido es pan. Entonces compara la transformación inmediata del pan de la Eucaristía en el cuerpo del Logos, hecha por este, con la transformación divinizante del cuerpo de Jesús, en cierto sentido también pan, por la inhabitación del Logos en él. Ambos panes son transformados por el mismo Logos.

(70) XXXVII, 96, 7. Cf. VIII, 35, 10.

(71) $\mathrm{V}, 15,18 \mathrm{~s}$.

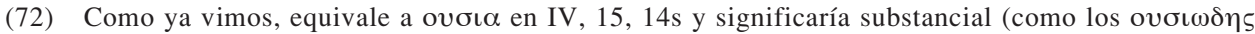

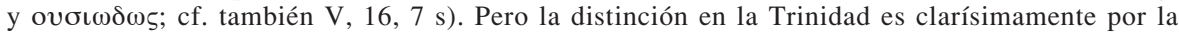

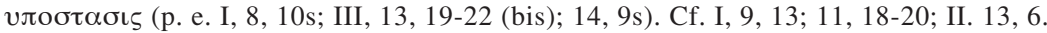

(73) Esto no está matizado respecto a la única libertad divina (libre albedrío respecto a la creación),

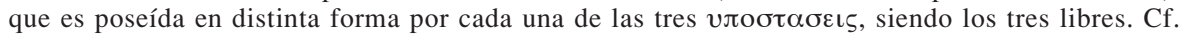
S. Zañartu, Trinidad y mundo plural. Algunas elucubraciones, Teología y Vida 42 (2001) $327-$ 347 , p. 340 s. 
autor que, reafirmada la divinidad del Logos y del Espíritu en el siglo IV, afirma a la vez los polos de la unidad y de la distinción. Por lo demás, el discurso parte probando el Dios uno contra el politeísmo helénico, limitando lo útil de este a la

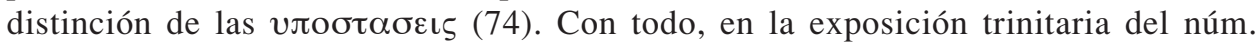
III, primero se menciona la distinción y después la unidad (75).

Pero el vocabulario trinitario aparece en relativamente pocas páginas. $\mathrm{Y}$ en su discurso racional, su centro trinitario es el Logos, no el Hijo. Así queda bastante marginado el correspondiente nombre de 'Padre'. Los tres de la Trinidad son padre del cristiano. Podría dar la impresión que la unidad no estuviera centrada en el Padre sino en la naturaleza divina. Así, contrapuesto a lo distinguido en Dios, es la unidad de naturaleza la que no acepta la separación para que el poder ( $\rho \alpha \tau о \varsigma)$ de la monarquía no se parta en pedazos, en divinidades diferentes (76). De paso habla explícitamente sobre la relación entre el Padre y Logos, en cuanto que el segundo implica al primero. Por lo demás, la relación se supone en un genérico 'de quien' (77), 'de donde', etc. (salvo lo que implican las escasas expresiones, como 'Dios unigénito', 'Padre', 'Hijo'). Por algo es llamado el Logos de Dios. También para el Espíritu de Dios se usa el 'de quien'. Además, Logos y Espíritu son comparados a los del hombre, y es afirmada su diferencia como divinos. La palabra humana respecto a su vous es lo mismo (lo manifiesta) y a la vez es otro. Es interesante que el Espíritu acompaña inseparablemente al Logos y manifiesta su actividad, como el hálito a la palabra.

\section{DIOS Y SU CREATURA}

Aquí solo pretendo enumerar algunos aspectos, en forma sucinta, para complementar lo ya visto sobre la Trinidad y preparar el entorno de lo que veremos sobre la economía humana de Dios, obteniendo así una visión más completa del Dios de esta obra. Comienzo por algunas indicaciones sobre los vocablos: $\theta \varepsilon$ $\varsigma$ es usado 150 veces, to $\theta \varepsilon$ เov 37 veces (78) y $\theta \varepsilon$ cotns 29 veces. Ya hemos visto que todo fue creado por el Logos, y que la Trinidad íntegra es increada (79). La dignidad de Dios

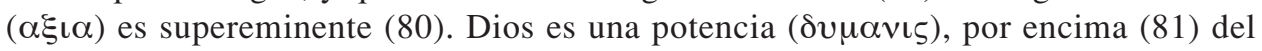

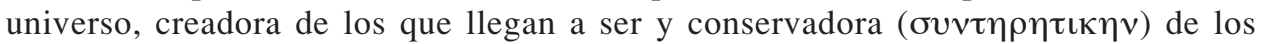

(74) Esto, por lo demás coincide con que el cristianismo se desarrolla a partir del judaísmo, pese a una cierta pretendida línea media entre helenismo y judaísmo de Gregorio. En este avanzar la verdad por entre ambos, está también insinuada la influencia de ellos en las respectivas herejías de lado y lado.

(75) Así se contrapone el op $\alpha \tau \alpha \iota$ de la distinción al $\kappa \alpha \tau \alpha \lambda \alpha \mu \beta \alpha \nu \varepsilon \tau \alpha \iota$ de la unidad (III, 13, 18s).

(76) III, 13, 22-26.

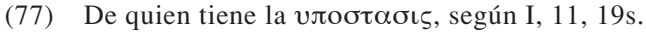

(78) El adjetivo $\theta \varepsilon \iota \varsigma_{\varsigma}$ es usado, en general, 114 veces. El adjetivo $\theta \varepsilon \iota \kappa o \varsigma$ aparece 4 veces.

(79) XXXIX, 100, 3; 100, 17s (de naturaleza increada); 101, 24 (naturaleza increada).

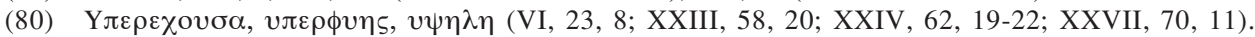

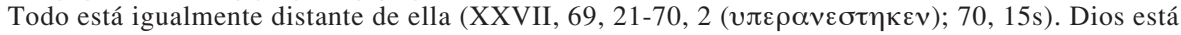
por encima de toda gloria y grandeza (XIV, 43, 6; cf. XV, 44, 14s). Véase II, 13, 3; XXVII, 69,

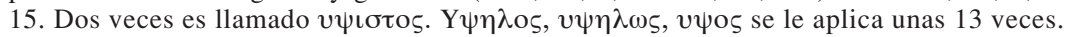

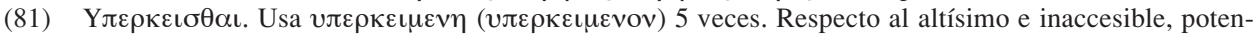
cia que rige todo el universo, dada la alteza de su naturaleza, toda creatura está igualmente distante y

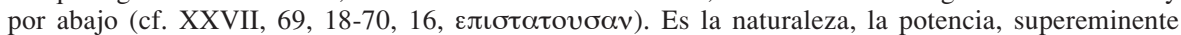

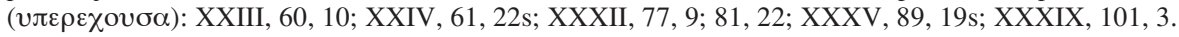


que son (82). Lo hizo todo con el solo impulso de su voluntad (83). Los seres ( $\tau \alpha$ ov $\tau \alpha$ ) dependen del que es ( $\tau$ o ov), y nada puede existir sino tiene su existir en el que es (84). Así, los seres están divididos en dos: lo creado y lo increado. Y la naturaleza increada posee en sí misma la inmutabilidad y la estabilidad, contrariamente a lo creado (85). Así, cuanto pasó a subsistir desde el no ser por obra de la naturaleza increada (86), habiendo comenzado a ser por mutación, siempre procede luego por vía de alteraciones (87). Por tanto, la gran diferencia de lo increado, en cuanto tal, respecto a lo creado es la inmutabilidad (88).

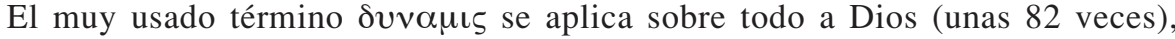
aunque también tenga algunas referencias al hombre como sujeto de ella o se deno-

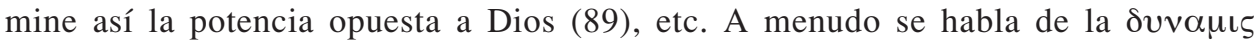
divina o de Dios (90). Pero lo que podría llamar la atención es que el mismo Dios

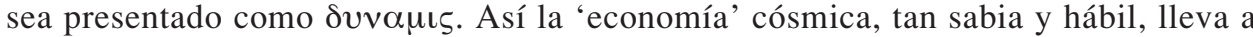

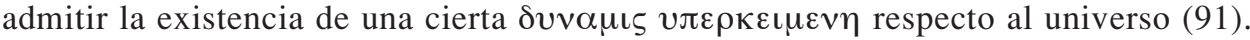

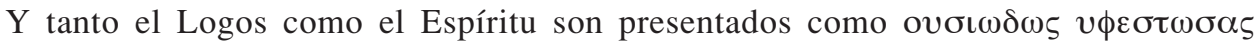

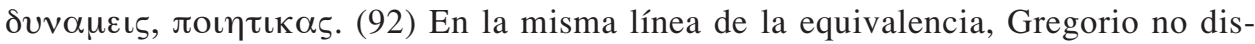

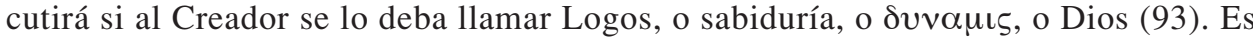

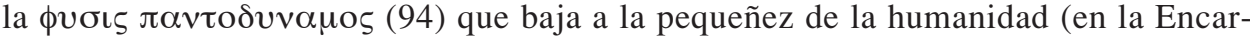
nación). ¿Hay en lo anteriormente dicho una cierta onto-teología, lo que podría ser adecuado a rasgos de mentalidad griega?

Observemos, entonces, el uso de $\phi v \sigma ı \varsigma:$ de unas 240 veces en que Gregorio usa este vocablo, 63 (95) veces estarían referidas a la naturaleza de Dios y unas 143

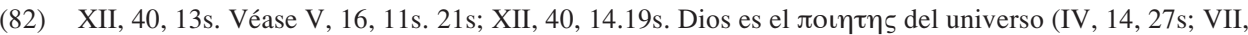
28,11 s, etc). A propósito del problema del mal, hace una gran defensa de Dios creador del hombre.

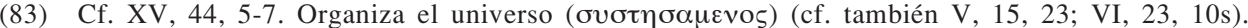
Véase XXIV, 61, 10-13; XXXV, 91, 8. Reúne (el crucificado) todas las cosas en una sola armonía (XXXII, 79, 21-80, 2; ib., 12-15).

(84) XXV, 63, 20-64, 3. Él está en todo y todo en Él. Véase XXV, 64, 3-7 ( $\pi \alpha \rho o v \sigma ı \alpha)$. Mantiene nuestra naturaleza en el existir, siendo la naturaleza divina lo que propia y primariamente existe; se coextiende a través de todos los seres (XXXII, 79, 12-17). Cf. XXXII, 80, 6-15.

(85) XXXIX, 99, 5-9. Cf. VI, 24, 1-6; XX, 54, 5-7; XXXIX, 100, 2-7. Dios es impasible (VI, 25, 16; véase el argumento del interlocutor en XVI, 45, 23-46, 2).

(86) Cf. también XI, 40,1s

(87) VIII, 35, 16-20. Cf. XXI, 55, 8-56, 10. Lo que está sujeto a alteración no permanece absolutamente en el ser. El movimiento del libre albedrío de la creatura le abrirá el camino a la explicación del mal.

(88) Por el bautismo, el cristiano entra a la vida inmutable (XXXIX, 100, 2-19). Cf. XXXIX, 99, 21s.

(89) Cf. VI, 22, 21s; 24, 6s; XXIV, 62, 4.

(90) Lo propio de la $\varepsilon v \varepsilon \rho \gamma \varepsilon \iota \alpha$ divina es la salvación de los que la necesitan (XXXVI, 92, 16s). Se está refiriendo al agua del bautismo.

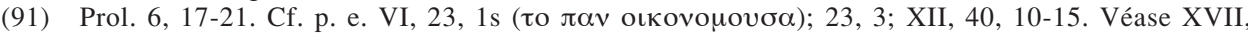
$70,3 \mathrm{~s} .12 \mathrm{~s}$.

(92) IV, 14, 17s. Cf. p. e. II, 13, 5; V, 16, 7s. Véase II, 12, 7; V, 16, 10s.23; XXXII, 81, 22; XXXV, 89, 19s. El Logos es $\alpha v \tau o \delta v v \alpha \mu \iota \varsigma$, según VIII, 35, 10s. Respecto a la fuerza creadora, véase $\mathrm{p}$. e.: V, 16, 10-12; 16, 20-17, 1; VI, 24, 4-6; VIII, 35, 10s; XXI, 55, 11-13; XXIV 61, 10-13. El

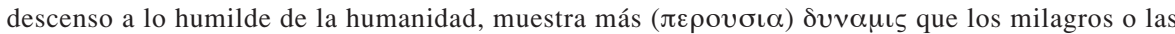
maravillas de la creación (XXIV, 61, 4-62, 3).

(93) V, 16, 16-18. Véase Prol. 8, 3-6; I, 11, 22-12, 3; XXXII, 80, 8-12.

(94) XXIV, 61, 4-7. Cf. Prol. 7, 6-11; II, 12, 26. El Logos puede todo lo que quiere (I, 10, 2-26; II, 13, 9-12; V, 16, 8s; VIII, 35, 12-16). Cf. XII, 41, 2 s.

(95) En 4 ocasiones se refiere a la unidad de la naturaleza divina. Cf. también I, 11, 11s. 21. Según XIV, 43, 6, Dios es un $\pi \rho \alpha \gamma \mu \alpha$. Cf. II, 12, 21. 
a la naturaleza humana (96). La naturaleza de Dios es connotada, en su contexto más

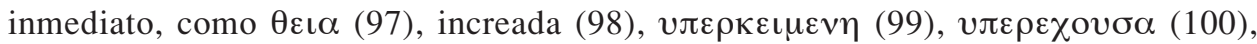
inmutable (101), inaccesible (102), etc. Es la naturaleza omnipotente (103), $\beta \alpha \sigma \iota \lambda \varepsilon v o v \sigma \alpha$ (104). Pero aunque se utilice el mismo término $\phi v \sigma ı \varsigma$ para Dios y para nosotros, el Creador, en su $\lambda$ o ${ }^{\circ} \varsigma$ y en su $\pi v \varepsilon v \mu \alpha$, no debe ser 'humanizado' ( $\varepsilon \xi \alpha \nu \theta \rho \omega \pi \iota \xi o \iota \tau o)$ según la semejanza de nuestra naturaleza (105). La divina naturaleza difiere por su magnificencia de la nuestra mortal y perecible (106). Nuestra perecible naturaleza tiene un $\lambda$ oyov perecible, pero la incorruptible y que siempre permanece, un $\Lambda$ oyov eterno y subsistente (107). Ella es lo que propia y primariamente es (ov), y así, nada puede permanecer en el ser sino permanece en el que es $\left(\varepsilon \vee \tau \omega_{\imath}\right.$ ov $\left.\tau \iota\right)$ (108). Por los beneficios podemos llegar por analogía a la naturaleza del que los obra (109). Por tanto, nuestro autor hace una clara diferencia entre la naturaleza divina y la humana.

Dios es perfecto y, como hemos visto, esto constituye el fundamento de la prueba de la unicidad de Dios contra el politeísmo (110). Es infinito ( $\alpha \pi \varepsilon \iota \rho o v)$ (111), simple (112), eterno (113), incorruptible (114) Es magnífico (115). Es la pureza verdadera (116), la verdadera virtud (117). Lo propio de la naturaleza de Dios es la verdad (118). Los atributos en que más insistirá en la polémica respecto a

(96) Las 35 veces restantes, según mis cálculos aproximativos, se referiría a la naturaleza de los seres, etc.

(97) Unas 21 veces. Véase XXXII, 80, 8; XXXIX, 100, 20

(98) 6 veces.

(99) 2 veces

(100) 2 veces.

(101) Unas 5 veces con diversos vocablos. Véase también VI, 25, 16; XVI, 46, 1.

(102) XXVII, 70, 2. Altísimo e inaccesible por la alteza de su naturaleza (XXVII, 69, 19ss,

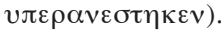

(103) XXIV, 61, 5.

(104) V, 20, 1.

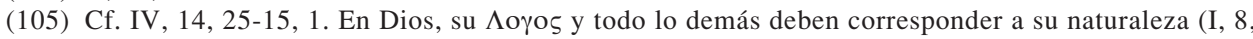
22-24). Cf. I, 9, 3-11.

(106) Cf. XI, 39, 19-21. Al bautizarse correctamente, el hombre elige por padre a la Trinidad increada;

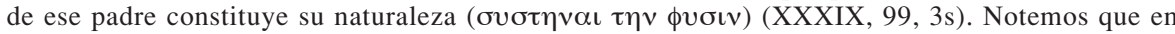
XXXV, 90, 5-9, al comparar, según verosimilitud, lo obrado, según la potencia divina, al sumergirse Cristo en la muerte, con lo obrado, según la potencia humana, por el cristiano que desciende al agua del bautismo, no se encuentra diferencia en cuanto cada uno obra lo que está en su poder según la medida de su naturaleza. Es una comparación que podríamos llamar de proporcionalidad, y según verosimilitud.

(107) I, 9, 8-11.

(108) Cf. XXXII, 79, 14s.

(109) Cf. XV, 43, 11-15.

(110) Cf. además Prol. 7, 6-11; I, 11, 24-12, 1. Véase XXXIX, 100, 15s. Hay que atribuirle a Dios (o al Logos) todo lo superior (V, 16, 16-18; XX, 53, 8-11; XXI, 57, 3-6; XXXII, 80, 8-11). Cf. XXIV, $62,19-23$.

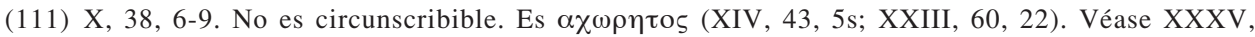
90,11 .

(112) Véase lo dicho sobre la naturaleza del Logos en I, 9, 20-26. Cf. I, 10, 10; XXVII, 70, 6-8.

(113) 8 veces se usa $\alpha \iota \delta \iota s$ y afines respecto a Dios o su Logos; y $\alpha \varepsilon \iota$, unas 4 veces.

(114) Unas 9 veces. Cf. I, 11, 24;XII, 41, 4; XIII, 42, 8; XXIV, 62, 24s. En XI, 40, 2, la naturaleza increada es llamada $\alpha \sigma \omega \mu \alpha \tau o s$.

(115) Su naturaleza es $\mu \varepsilon \gamma \alpha \lambda$ oл $\rho \varepsilon \pi \varepsilon \sigma \tau \varepsilon \rho \circ$ s respecto a la mortal (XI, 39, 19s).

(116) XXXVI, 92, 19s

(117) XV, 45, 11.

(118) XXXIV, 84, 15s (cf. Ib., 84, 21-85, 3). 
lo $\theta \varepsilon о \pi \rho \varepsilon \pi \eta \varsigma$ de la economía humana de Dios, serán: bondad (119), sabiduría (120), justicia (121) y poder. Estos cuatro (122) tienen que ir siempre juntos: de lo contrario, dejan de ser virtud (123). Su aplicación la veremos después.

Pasemos ahora a otros rasgos de Dios y de su acción. Es llamado 'Señor' en textos del A. T. (124) Dios tiene la libre disposición del universo (125), y con su poder cognoscitivo domina por igual lo futuro como lo pasado (126). Y es un Dios providente, con una continua economía respecto a los seres (127). Dios muestra la sobreabundancia $\left(\pi \varepsilon \rho \iota \sigma^{\circ} \alpha\right)$ de su amor al crear al hombre (128), y de su poder al descender a lo más bajo (129) en la Encarnación. Es propio de Dios el dar la vida (130) a los hombres, conservar con su Providencia (131) a los seres, dar liberalmente comida y bebida a los que les ha tocado vivir en la carne, hacer el bien al que lo necesita, restablecer de nuevo mediante la salud a la naturaleza alterada por la enfermedad, señorear (132) de igual manera sobre toda la creación, sobre la tierra, el mar, el aire y las regiones por sobre el aire, y tener el poder suficiente para todo y, antes que nada, ser superior a la muerte y a la corrupción (133).

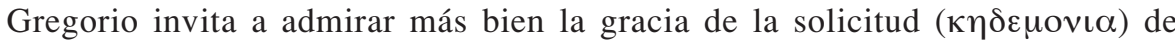
Dios por nosotros, que llega al exceso $(v \pi \varepsilon \rho \beta o \lambda \eta)$ de su acción benéfica al introdu-

(119) De ella trataré a propósito de que Dios no es el autor del mal.

(120) Unas 39 veces se atribuye a Dios o a la creación y economía realizadas por Dios. En XV, 45, 9, el Dios que se encarna es llamado $\alpha v \tau$ toбoфı $\alpha$.

(121) Unas 26 veces se refiere a la justicia de Dios y de su obra. Pero, salvo Prol. 8, 3 y el justo juicio de Dios correspondiente a nuestra libertad después de esta vida (XL, 106, 12), las citas se concentran en la justicia del rescate respecto al adversario, en los números XX a XXVI. En XXVI, 64, 24 s, dice que es propio del justo dar su parte a cada uno según su valor (cf. XXVI, 65, 2s.5-7.8-12.20-25; XL, 106, 11-13). En Dios no hay injusticia (XL, 105, $2 \mathrm{~s}$ ).

(122) XX, 53, 8 ss; XXI, 57, 3ss; XXIV, 62, 23-63, 8. Cf. Prol. 8, 3 s. Véase también: XXIII, 60, 13-23; XXVI, 64, 24ss; 66, 2s.

(123) Cf. p. e. XX, 53, 8-25. Los pensamientos sobre Dios deben estar concatenados el uno con el otro en secuencia lógica (XXIV, 62, 21-23).

(124) IV, 14, 22-24; 15, 12; XL, 105, 1.2. Cf. VIII, 30, 6. A Jesucristo solo se le aplica en XXXIX, 101, 21.

(125) XXX, 75, 13

(126) VIII, 34, 9-11. Cf. V, 16, 22; VII, 26, 13s.20s; VIII, 34, 11-15.

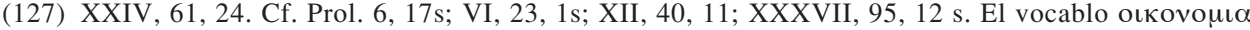
(y el verbo y una vez el adverbio correspondiente) 29 veces está referido a la acción de Dios, normalmente a la economía según el hombre, 2 veces llamada economía de muerte. La introducción de la muerte como purificación del mal para reconstruir al hombre en la resurrección, es llamada 'economía' (XXXV, 88, 18-21 (perfecta en el caso del guía de nuestra salvación); cf. VIII, 30, 16-18; XXXV, 88, 13s; 91, 7-9). También se usa algunas veces para el añadido final sobre el bautismo, etc., p. e. economía mistérica ( $\mu v \sigma \tau \iota \kappa \eta)$, de la gracia. Algunas otras veces se refiere a una economía más general o aun cósmica, como es el caso citado que dio ocasión a esta nota. En XXV, 64, 1s aparece la expresión 'economía del misterio', referida a la Encarnación (véase XVI, 49, 8s)

(128) V, 17, 2s. Véase VIII, 29, 5s; XXX, 75, 13-15 ( $\tau \varepsilon \varepsilon \rho \beta о \lambda \eta)$. La potencia divina es la que transforma el semen en naturaleza humana (XXXIII, 83, 13ss). Cf. XXXIV, 85, 7-9.

(129) XXIV, 61, 13-15. Véase XXXII, 77, 9s.

(130) Cf. también VI, 22, 14s; VIII, 29, 12; 35, 14s; 36, 12, etc. El cristiano hace a la naturaleza inmutable, fuente ( $\alpha \rho \chi \eta \gamma$ ov) de su propia vida (XXXIX, 99, 22; cf. $I b ., 100,18 \mathrm{~s}$ ). Es engendrado por el Padre y por el Hijo y por el Espíritu Santo (Ib., 99, 15s).

(131) $\Delta \iota \alpha \pi \rho$ ovoı $\alpha$. También usa $\pi \rho$ ovoı $\alpha$ en XXXV, 88, 14. Utiliza $\pi \rho \circ \eta \eta \theta \varepsilon \iota \alpha 3$ veces.

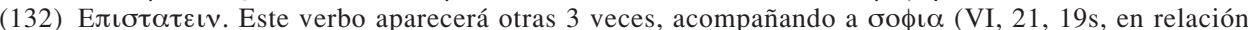
a la armonía sinfónica de los contrarios en el mundo sensible), a $\varepsilon \xi o v \sigma \iota \alpha$ (VI, 22, 21) y a

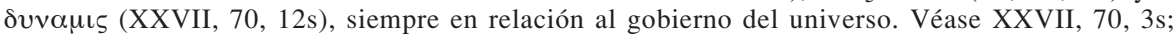
XXXV, 90, 3s.

(133) XII, 40, 19-41, 4. 
cir la muerte purificadora en vista a la remodelación del hombre por la resurrección (134). Dios está en todas partes, como ya hemos visto, y asiste a los que invocan su poder vivificador y obra lo que le es propio (135). Se hace presente para santificar lo que se realiza en el bautismo, cuando se lo invoca (136). Llama a todos por igual a la fe (137). Inspira (138). Propio de Dios es la salvación de los que lo necesitan (139), restablecer al hombre que había caído (140). Característica propia es la filantropía (141). Dios, en su plan de salvación, es el bienhechor del hombre (142).

Las características de Dios, vistas hasta aquí en la Catequesis de Gregorio (143), están bastante en torno a una presentación y defensa del Dios razonable. Pero son interesantes las rápidas pinceladas bíblicas en la última parte respecto a los rasgos de Dios que debe tener el que verdaderamente nace de Dios en el bautismo. Dios abre su mano y llena a todo viviente de su benevolencia. Pasa por encima de las transgresiones y se arrepiente de la desgracia. Es bueno para con todos (144). No ejerce su cólera cada día. Es un Señor recto y no hay injusticia en Él (145).

Surge la pregunta, ¿cómo conocemos a Dios? Existe una $\theta \varepsilon$ covw escudriña cuidadosamente las profundidades del misterio del Dios trinitario, alcanza alguna modesta inteligencia en su alma respecto a lo inefable (146). Pero no puede esclarecer con la palabra la hondura inexpresable de este misterio (147). Como la

(134) VIII, 29, 4-8.20s. Cf. Ib., 30, 10-13.

(135) XXXVI, 92, 14-16.

(136) XXXIV. Ha prometido estar en medio de los creyentes, permanecer en todos y unirse a cada uno (XXXIV, 84, 17-19). Véase XL, 104, 15.

(137) $\mathrm{XXX}, 75,1-11$

(138) XXX, 75, 9 s. Cf. IV, 14, 19s.

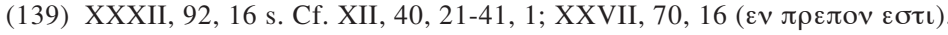

(140) VIII, 36, 9-16. Cf. XXVI, 66, 4s.

(141) XV, 43, 15 s. 4 veces más aparece la filantropía divina.

(142) 13 veces usa los términos $\varepsilon v \varepsilon \rho \gamma \varepsilon \tau \eta 5, ~ \varepsilon v \varepsilon \rho \gamma \varepsilon \sigma \iota \alpha$ y el verbo correspondiente en este sentido. En 3

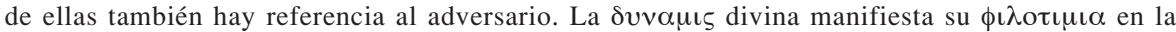
multiplicación de los panes y peces (XXIII, 59, 13s).

(143) Nuestro autor siempre deja abierto el que haya otros nombres o pensamientos piadosos y dignos de Dios. Cf. p. e. Prol. 7, 8s; 8, 5; I, 12, 1s; V, 16, 17 s; XV, 45, 10; XX, 53, 10 s; XXI, 57, 5 s; XXXII, 80, 9-11. Véase XXIV, 62, 19-22.

(144) En otra cita bíblica habla del $\pi \lambda \eta \theta 0 \varsigma \tau \eta \varsigma \chi \rho \eta \sigma \tau o \tau \eta \tau o \varsigma$ de Dios (XVII, 50, 9).

(145) XL, 104, 18-105, 3.

(146) Velasco traduce: "puede captar en su alma de manera inefable". Similar es la traducción de Barbel.

(147) III, 13, 12-17. Igualmente, examinando con cuidado el misterio se podría decir, con mayor razón, que el nacimiento ha sido asumido por Dios a causa de la muerte (XXXII, 77, 21-24). En el Evangelio todo ha sido dicho y realizado según un sentido ( $\lambda$ o yov) más alto y divino (XXXII, 79, 3-

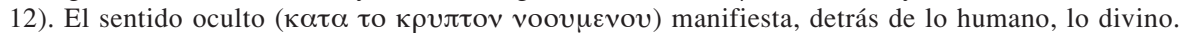
Por tanto, en el modo de morir hay que investigar lo más divino. Pablo inicia en el misterio (de la cruz) a los Efesios, capacitándolos para conocer, mediante la enseñanza, la profundidad, altura, anchura y largura de este (XXXII, 80, 18-21). Gregorio deja irónicamente a los expertos en cosas ocultas alguna otra palabra más profunda sobre la cruz, contentándose él con lo que llega por la tradición (XXXII, 78, 19-79, 3). Una mala interpretación hizo a los judíos observar la letra de la ley más que su espíritu (XVIII, 52, 13 s). Cf. VIII, 30, 1-3; XVIII, 52, 6-8: XXXV, 88, 4 s; XXXIX, 101, 19-23. El mismo Gregorio, en XXXV, 87, 12-14, dice usar un lenguaje trópico.

El hombre creado por Dios estaba dotado de todos los bienes dignos de Dios para que, mediante ellos, deseara lo oıkeıov. Uno de ellos era la eternidad. Por eso tenía la inmortalidad, para que, mediante esta potencia ínsita en él, conociera lo que está por encima ( tuviera el deseo de la eternidad divina. Esto lo muestra el Gn al decir que fue hecho a imagen de Dios. En la semejanza según la imagen se halla enumerado todo lo que caracteriza a lo divino (V, 17, 23-18, 9). Gozaba de la manifestación de Dios cara a cara (VI, 25, 17s). 
creatura es muy diferente de Dios, p. e. en su logos y hálito, aunque usamos la homonimia (148) para hablar de ellos, lo hacemos anagógicamente (149). Todo lo que se dice de Dios, a la vez hay que elevarlo (150). Le atribuimos a Dios lo más alto, lo digno de Dios (151). Y en esto están todos de acuerdo. Justamente, que sea digna de Dios es lo que objetan los interlocutores a la economía humana de Este. Gregorio se esmerará en mostrar lo razonable de la economía, no habiendo nada inverosímil en ella (152), ni indigno. Y aunque no la podemos entender (153), sin embargo, podemos conjeturarla ( $\sigma \tau 0 \chi \alpha \sigma \mu o v \tau \iota v \alpha)$ con ejemplos (154), en los que obviamente no se aplica todo sino lo conveniente (155). A Dios solo lo conocemos, analógicamente, por su acción, por sus beneficios (156). No se podría tener otra prueba de que Dios absolutamente existe, sino por el testimonio de sus actividades (157). Por eso, el que busca las pruebas de la Encarnación que mire las actividades, los milagros, que son propios de Dios (158). Así, no dudamos que Dios haya nacido en una naturaleza humana, gracias a los milagros (159), entre los que se cuenta su nacimiento virginal y su muerte, que, en vez de corrupción, termina en resurrección (160).

En la fe aceptamos lo que nos enseña el misterio de la verdad (161), las enseñanzas mistéricas (162), la Escritura (163) (incluyendo Nuevo Testamento), el

(148) I, 8, 19-9, 11. Es necesario que todo corresponda a la respectiva фvoıs. También hablará de una homonimia respecto al fuego y gusano del castigo después de esta vida (XL, 105, 16-106, 10).

(149) II, 12, 4ss. No hay que rebajarlos hasta nuestra pequeñez. Según IV, 14, 25-15, 11, si el Logos y el Espíritu fueran semejantes a nuestra palabra y hálito, estaríamos haciendo humano lo divino.

(150) I, 9, 3-5.

(151) Como ya vimos a propósito de la perfección de Dios. En el Logos encontramos los mismos $\gamma v \omega \rho \iota \sigma \mu \alpha \tau \alpha$ que en el Padre (I, 11, 20-12, 3). Hay cosas que caracterizan lo divino (V, 18, 7-9), su naturaleza (XII, 40, 17-19). Cf. XV, 43, 11-18; XL, 104, 16-18.

(152) XXIV, 63, 11s; XXXII, 78, 17-19. Cf. XXXII, 81, 8-10; XXXIII, 84, 1-5. Véase XXXVII, 96, 2 s.

(153) Como ya vimos al comienzo, a propósito del misterio, el cómo Dios nace en una naturaleza de hombre supera el curso de nuestros razonamientos. También hay misterios de la naturaleza que no entendemos, como la unión del alma con el cuerpo, y el modo de constitución del universo.

(154) $\mathrm{X}, 38,20-23$

(155) X, 39, 1-4

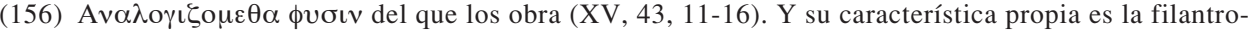
pía. Usa el verbo $\varepsilon \pi \iota \gamma \iota \gamma \nu \omega \sigma \kappa \omega$. Puede verse también XX, 54, 17-22.

(157) Economías cósmicas y beneficios divinos respecto a la vida.

(158) XII, 40, 6-19. Y en XII, 40, 19-41, 4 enumera algunas de estas actividades propias de Dios. Los milagros prueban, porque están por sobre la naturaleza (XIII, 41, 18-43, 2). Así lo de Jesús

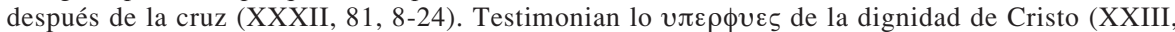
$58,20)$. Véase XXIV, 61, 15-22. Pero el abajarse de la naturaleza omnipotente a la pequeñez de

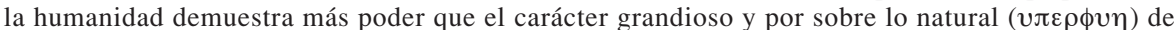
los milagros o las maravillas de la creación (XXIV, 61, 4-62, 3).

(159) XI, 39, 22-24. Cf. XXXIV, 84, 11-13.20s; 86, 3s. Véase XXIII, 60, 8-13. También contribuye el testimonio de lo sucedido al paganismo y al judaísmo (XVIII).

(160) Cf. XIII. En XXIII, 58, 16-60, 5 enumera alguno de los milagros (entre ellos el nacimiento virginal), gracias a los cuales el adversario lo aceptó como rescate. Bajo otro punto de vista y a propósito de que el temor a la manifestación divina no impidiera el plan salvífico, la potencia divina se hizo comprensible ( $\chi \omega \rho \eta \tau \eta v)$ mediante la envoltura de la carne (XXIII, 60, 14-16; cf. Ib., 60, 21-23).

(161) Que Dios en el principio ha creado al hombre y que habiendo este caído, lo ha salvado (VIII, 36, 14-16). Cf. IX, 37, 3-5; XVI, 46, 12s; 47, 7s.10s; XXIV, 63, 11-16; XXV, 64, 1s; XXVI, 67, 13 15; XXVIII, 71, 9s; XXXII, 78, 17-19; 81, 7-10. Véase XXXVIII, 98, 8s.

(162) XXXII, 82, 1s. Véase Prol. 5, 1.3s.7-9; III, 13, 14s; XXXIII, 82, 15; XL, 102, 4s.

(163) Según Winling (op. cit., 125), il s'agit d'une utilisation progressive correspondant pour ainsi dire au cheminement de ceux qui, acceptant la démonstration, pénètrent de façon progressive dans le secret de la doctrine chrétienne. 
kerygma (164), lo que viene de la tradición (165), etc. Dicho esto y a pesar de las afirmaciones sobre el misterio indecible, que vimos en la Introducción, y de la diferencia entre Creador y creatura, queda la impresión de que en este escrito, donde se presenta un Dios razonable, no se destaca mucho el momento de una teología negativa.

\section{LA BONDAD DE DIOS Y EL MAL DEL HOMBRE}

Gregorio, habiendo presentado el Dios uno y trino y antes de enfrentar lo razonable de la economía de Dios por nuestra salvación, responde al problema del mal respecto al hombre, principalmente en los números V a VIII, diciendo que Dios todo lo creó bueno, que Él no es el autor del mal. Obviamente, en este punto, sus adversarios no son el judío ni simplemente el griego (166), ni varias de las herejías. Los únicos que nombra son las doctrinas maniqueas, a las que se han dejado arrastrar los que quieren demostrar que el creador de la naturaleza humana es malo (167). Y, como ya dijo al comienzo, los 'prejuicios' de estos son diferentes a los de otros y, por tanto, la terapia debe ser diferente. Con todo, el problema seguirá apareciendo en la obra y así tendrá que demostrar que la economía de Encarnación, cruz, etc., no tiene nada de malo.

Si nos fijamos en los vocablos, $\alpha \gamma \alpha \theta 0 \tau \eta$ prácticamente siempre (16 veces) está referido a Dios (168), y $\alpha \gamma \alpha \theta$ os 17 veces en forma directa (169). Afirmación fundamental y muy repetida es la bondad de Dios y de su Logos creador y de su Espíritu. Como hemos visto, tanto el Logos como el Espíritu son potencias libres, que siempre eligen el bien y que pueden realizarlo. Y Dios había sido declarado perfecto en bondad (170). Para pasar a la creación del mundo, que es bueno ( $\alpha \gamma \alpha-$ $\theta 0 \varsigma)(171)$, afirma enfáticamente, aun antes de tratar de la relación entre Dios y el

(164) 6 veces aparece este término.

(165) XXXII, 79, 2. Cf. XXVI, 67, 13-15; XXXIX, 99, 13s. Véase Prol. 5, 1-5; I, 8, 10s; VI, 21, 4s.

(166) La unicidad de Dios plantea con más fuerza el problema del mal.

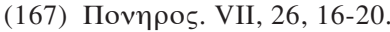

(168) De las 17 veces que aparece en el texto, solo se exceptúa VI, 25, 1. El más manifiesto testimonio de su bondad es venir él mismo en busca del que se había pasado al enemigo (XX, 54, 3-7). Cf. XXII, 57, 24-58, 4; XXIII, 60, 19s; XXIV, 63, 1s; XXVI, 65, 3s.7s.

(169) Excluyo, por tanto, las veces en que $\alpha \gamma \alpha \theta$ os se refiere a los bienes divinos, en los que participa el hombre. Dios sería el que siempre permanece en la perfección del bien (XXXIX, 100, 15s; cf. XX, 54, 6s; XXXIX, 99, 11s). En cambio, para el hombre el progreso en el bien no tiene límite (cf. XXI, 55, 23-56, 1). Dios, siendo bueno, se compadece del caído (XXI, 57, 6s). En XL, 105, 1, se aplica al Señor $\chi \rho \eta \sigma \tau o s$, para con todos. Véase XVII, 50, 9. Respecto a la economía de salvación, Gregorio habla 5 veces de $\phi \iota \lambda \alpha v \theta \rho \omega \pi \iota \alpha$, que es propia de Dios y causa de su venida (XV, 43, 15-18).

(170) Prol. 7, 7-11. Véase $I b ., 8,3$ s. A propósito de que el Logos no tiene inclinación a nada malo, Gregorio afirma que el impulso hacia lo malo es ajeno a la naturaleza divina (I, 10, 13-15). Véase I, 11, 22s; XXVIII, 71, 7s.

(171) Esta afirmación de la bondad del cosmos, hábil y sabiamente dispuesto, parece surgir inmediatamente, y no como conclusión de que el Creador es bueno, sino que, dado que el mundo es bueno, entonces ha sido creado por el Logos, es su obra (cf. I, 10, 18-20). Más claramente lo dice Gregorio a continuación en I, 10, 23-26. Véase V, 16, 9-11. En que el mundo es bueno, se estaría, pues, de acuerdo (cf. también V, 15, 22-16, 5); correspondería a una cultura de su época. Recordemos, por lo demás, que también la existencia de Dios ha sido deducida de ese mundo, y que el Logos engloba toda la potencia creadora (VIII, 35, 10s; véase V, 16, 13-16). Tratando del nacimiento, dice que si se acusara a la naturaleza de algo vergonzoso e indigno, esta acusación

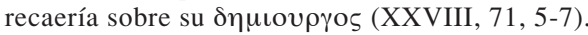


Logos y de hablar del Espíritu, que el Logos, que quiere lo que es bueno y puede realizarlo (172), no permanece inactivo sino que transforma en actos todos sus proyectos de bien (173). El Logos, pues, aparece muy conectado con el mundo. La bondad es un distintivo de Dios y del Logos (174). Y repite, una vez más, siendo el mundo bueno, su causa es la potencia oferente (175) y creadora de los bienes (176). Forma al hombre, no por necesidad sino por sobreabundancia de amor. Era necesario que su bondad no quedara sin disfrutarse al no haber quien participara y la gozara. Para esto es constituido el hombre, para participar de los bienes divinos (177). Así fue equipado con todos los bienes dignos de Dios, por tanto también con la inmortalidad (178). Es decir, fue hecho a imagen de Dios, como dice el Génesis (179). Nuestra naturaleza en el paraíso era buena y se hallaba entre bienes (180). Si, por bondad, el hombre fue traído a nacer, no se podría razonablemente levantar la sospecha de que este ahora nazca entre males (181) por causa de su Creador (182). Y el hombre era

(172) Cf. también I, 10, 21-23; 10, 25s

(173) I, 10, 15-18.

(174) Cf. I, 11, 22-12, 3

(175) Cf. J. H. Srawley, op. cit., ad 1. c.

(176) V, 16, 9-11. Cf. VIII, 35, 3-6. Dios constituyó todo según bondad, y no para el mal (VI, 23, 9-11).

(177) V, 16, 23-17, 11. Dios creó al hombre por bondad, dispuso en su naturaleza los principios de todos los bienes. El mejor de los bienes es la gracia de la libertad ( $\alpha \delta \varepsilon \sigma \pi 0 \tau o v, \alpha v \tau \varepsilon \xi o v \sigma \iota 0 v)$. Hizo al hombre para que participara de sus propios bienes (V, 19, 8-21). Respecto a crear al hombre, véase VII, 26, 15.23s; 28, 10-12; VIII, 34, 4s.13-17; 35, 3s.6s14-16: 36, 12-15; XVI, 46, 18s; XXI, 55, 6-8; XXVIII, 71, 5s, etc. El relato de Gn 2, 7, lo tenemos en VI, 22, 13-15. Véase VIII, 31, 17. El Creador mezcla con la naturaleza humana algo emparentado con lo divino para que sea impulsado hacia allá (V, 17, 13-16; cf. V, 17, 20-18, 4; 19, 15-19; VI, 22, 13-18). Véase también V, 20, 5; XV, 43, 21s; XXXVI, 92, 18-20.23-25; XL, 104, 16-18. En la construcción del hombre, nada se opone a la virtud (XV, 45, 16-21).

(178) V, 17, 23-18, 3. Cf. VIII, 30, 17s

(179) V, 18, 5-11. En la semejanza según la imagen está la enumeración de lo que caracteriza a lo divino. Revisemos los otros textos sobre el hombre como imagen y semejanza de Dios. El hombre, cuyo plasma terrestre es confeccionado, es llamado $\alpha \pi \varepsilon \iota \kappa o v \iota \sigma \mu \alpha$ de la potencia de arriba. To $\theta \varepsilon 0 \varepsilon \iota \delta \varepsilon \varsigma \kappa \alpha \lambda o \varsigma$ (cf. también VIII, 35, 15s) de la naturaleza inteligible estaba mezclado en él con cierta potencia indecible y se asemejaba a la dignidad suprema (VI, 23, 2-8). De elevada dignidad, encargado de reinar sobre la tierra y cuanto hay en ella, era hermoso en su aspecto (había llegado a ser $\alpha \pi \varepsilon \iota \kappa o v ı \sigma \mu \alpha$ del Arquetipo de la belleza), impasible ( $\sin \pi \alpha \theta$ os) en su naturaleza ( $\mu \iota \eta_{\eta} \alpha$ del Impasible), y gozaba de la manifestación divina cara a cara (VI, 25, 12-

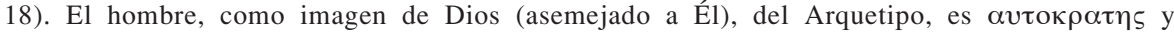
$\alpha \delta \varepsilon \sigma \pi$ бo 5 para que la participación de los bienes fuera premio de la virtud (V, 19, 21-20, 5). El

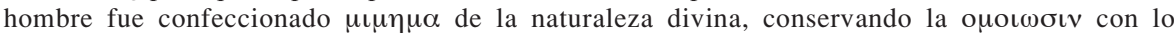
divino mediante todos los otros bienes y lo $\alpha v \tau \varepsilon \xi o v \sigma \iota v$ de su $\pi \rho 0 \alpha \iota \rho \varepsilon \sigma \iota \varsigma$ (XXI, 55, 6-8). Según VIII, 30, 16-20, la imagen divina estaría en el interior (V, 18, 20s habla de lo $\theta \varepsilon o \varepsilon \iota \delta \varepsilon \varsigma$ del alma), porque no es tocada por la mortalidad ( $\vee \varepsilon \kappa \rho \tau \eta \varsigma)$, que, por la caída, recubre lo exterior del hombre creado para la inmortalidad. El hombre, $\mu \iota \mu \eta \mu \alpha$ de la naturaleza divina, $\varepsilon \iota \kappa \omega v$ del Arquetipo, a quien se asemeja, difiere de Este por la mutabilidad, por el cambio (cf. XXI, 55, 1422). En XXXIII, 83, 22, el hombre es mentado como 'imagen de Dios'. Según VIII, 29, 20-22, texto críticamente dudoso, el hombre será remodelado por la resurrección según la forma original, si en la presente vida hubiere conservado el según la imagen. Véase XL, 103, 11 ( $\theta \varepsilon \iota \alpha \mu о \rho \phi \eta)$.

(180) V, 18, 11-16. Si algo de la naturaleza fuera tenido por vergonzoso e indigno, la acusación recaería sobre su demiurgo. Pero no hay nada de eso, porque lo único vergonzoso, por su propia naturaleza, es el mal (XXVIII, 71, 1-7). A continuación muestra Gregorio la dignidad de los órganos de la generación, que conservan la inmortalidad de la humanidad y en cierto modo vuelven ineficaz la muerte (XXVIII, 71, 19-72, 12)

(181) En V, 18, 17-19, 1, enumera algunos 'males' que parecerían contradecir la creación buena del hombre.

(182) V, 19, 8-12. Cf. V, 20, 8-10. 
una mezcla de lo inteligible y sensible para que nada de la creación quede excluido de la participación divina (183).

La causa del mal, que es ausencia de virtud, hay que buscarla en la libertad,

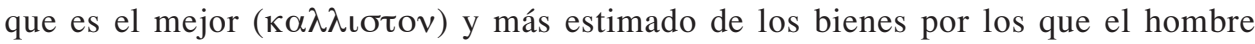
era semejante a Dios (184). La gran falta voluntaria del hombre se origina a partir de la envidia de la potencia angélica (185) encargada de gobernar el entorno de la tierra, al ver la semejanza con la dignidad suprema de alguien que estaba bajo su dominio (186). Esta potencia es la que induce al hombre al mal. Así fue el comienzo de todos los males presentes (187). El hombre, mudable como creatura, resbaló y cayó en todos los males (188). Pero objetarán, si Dios no ignora nada de los seres y previó esto, el creador de la naturaleza humana sería malo, porque al hombre quizás le sería más provechoso no existir. Crear al hombre iría contra la bondad de Dios (189). Sin embargo, según Gregorio, definir el bien por el placer corporal (sensible), es propio de carnales. La naturaleza humana está necesariamente sujeta a padecimientos y enfermedades, a su disolución, porque es compuesta. Lo único какоv es

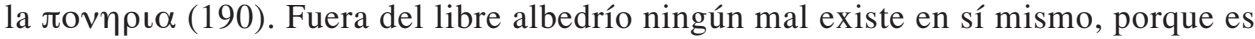
no ser (191). Y Dios no puede ser creador de lo que no subsiste. Dios hizo lo que es

(183) Cf. VI, 21, 16-22, 18. El mundo sensible, creado por Dios, tiene una cierta armonía entre los elementos contrarios y así se origina una sinfonía de la creación entera, sin ninguna disonancia. Dios mezcló lo inteligible con lo sensible para que nada de la creación sea desechado ni excluido de la participación divina. Para que todo lo terreno fuera elevado junto a lo divino y una sola gracia se pudiera extender, con igual honor, por toda la creación.

(184) Cf. V, 19, 12-20, 25. La libertad es connotada en este párrafo con las siguientes y numerosas

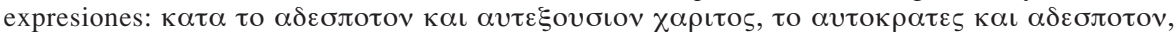

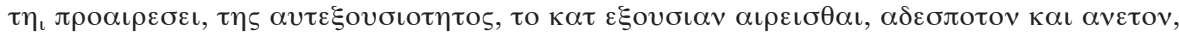
$\pi \rho о \varepsilon \lambda о \mu \varepsilon v \eta$. Véase XXX, 75, 13-17.

(185) No fue creado en maldad por el que constituyó el universo en bondad (VI, 23, 9-11).

(186) Esta potencia cayó en la pasión de la envidia por un movimiento de su libertad, porque como creatura era mudable (la misma existencia de la creatura parte del cambio: del no ser al ser). En la presente obra, Gregorio, sin pormenorizar, escribe para un auditor benigno.

(187) Cf. VI, 22, 18-26, 13. Es decir, con engaño persuade al hombre que se convierta en asesino de sí mismo y por su propia mano. Mediante el engaño, mezcla la maldad al libre albedrío del hombre. Véase también, p. e. XXI, 56, 16-57, 1.

(188) Cf. VIII, 35, 16-36, 6. Por un movimiento libre cayó de su felicidad, concebida como impasibili-

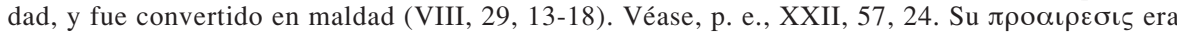

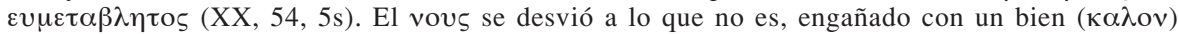
aparente (cf. XXI, 56, 10-57, 3).

(189) Cf. VII, 26, 13-27, 2. Véase VII, 27, 23-28, 1; VIII, 34, 4-7; 17-21.

(190) Discernir lo bueno y lo no bueno por las penas y placeres, es propio de la naturaleza irracional. Únicamente es malo, no lo sensible, sino la separación del verdadero bien (VIII, 34, 21-35, 3).

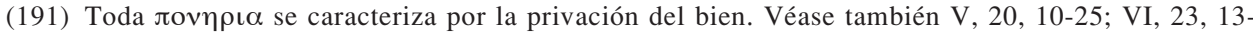
24, 1; 24, 21-25, 2; VIII, 31, 5-7; 34, 24s; XXI, 56, 2-6. La ausencia de la virtud es la génesis de la maldad. Según VI, 26, 5-9, faltando algo, por necesidad se introduce lo contrario (cf. VIII, 35, 25-36, 5). Véase VI, 24, 10s; XV, 44, 21-24; 45, 3-5.12; XXIII, 58, 8-10; XXIV, 63, 8-11; XXVI,

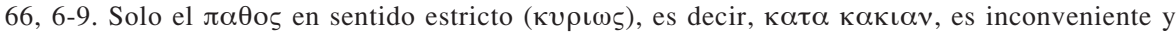
vergonzoso. Verdaderamente es $\pi \alpha \theta$ os lo que, ajustándose a la libertad, hace cambiar desde la virtud a la maldad. Y, en ese sentido, no es $\pi \alpha \theta$ o el movimiento según naturaleza, ni la disolución del compuesto, en que los elementos retornan a lo que les es afín (cf. XV, 45, 13s; XVI, 46, 3-14; véase también VIII, 30, 20-25; IX, 37, 12s). Es decir, la muerte no es $\pi \alpha \theta$ os (XVI, 47, 11 48, 2). Véase XXVIII, 71, 2s. La potencia divina podía enfrentar la muerte y entrar en ella, sin verse desviada al $\pi \alpha \theta 0 \varsigma$ (XXXV, 90, 11-13). La $\alpha \pi \alpha \theta \varepsilon \iota \alpha$ es el comienzo de la vida según la virtud (VI, 24, 18s) 
( $\tau \alpha$ ov $\tau \alpha$ ), y no lo contrario: inauguró la virtud (192); propuso bienes como premio de la vida virtuosa, porque no fuerza (193).

La muerte es tenida por el peor de los males (194), sin embargo, es un exceso del beneficio divino, en que Dios muestra su cuidado solícito por el hombre. ¿Tiene otra intención el proveedor de la vida, y no el que vivamos en las mejores condiciones? Al disolverse el hombre en la tierra, como jarro de arcilla, se separa la suciedad y puede ser remodelado en la forma original (195). La mortalidad (túnicas de piel), que era lo peculiar de la naturaleza irracional, fue aplicada al hombre por el médico de nuestra maldad, pero no es inherente a la naturaleza humana (196). Abraza la parte sensible del hombre sin tocar la imagen. La parte sensible se disuelve, pues, para ser remodelada de nuevo por la resurrección según la belleza primigenia (197). Pues, según la economía, la muerte fue introducida en la naturaleza humana por la Providencia divina para que en la separación del cuerpo y del alma se escurriera la maldad y el hombre fuera de nuevo restituido sano y salvo, sin $\pi \alpha \theta$ os, intacto y ajeno a toda mezcla de maldad (198). Pero ¿cómo extraer las manchas del alma? Por la virtud en esta vida, o en la otra por el tratamiento del juicio para reconducir a la gracia originaria, lo que va con dolores indecibles. El médico de los malos corta y raspa dolorosamente (199). Si Dios creó al hombre, a pesar de saber que se desviaría hacia el mal, no es porque tenga un impulso hacia el mal, sino porque a la vez contempló volver a llamarlo al bien. A Gregorio le parece que, en esas circunstancias, era mejor que trajera nuestra naturaleza a la existencia (200). Pero solo Él, el Señor de la naturaleza, el que había dado la vida, podía (y a la vez le correspondía) volver a llamar a la gracia del principio, al que había perecido. Así termina Gregorio esta sección sobre el mal, dando paso a la larga consideración de la conveniencia del nacimiento y muerte de Cristo: Dios ha creado al comienzo al hombre y ha salvado al que había caído (201). Por tanto, diríamos nosotros, la muerte no es propiamente un mal, y Dios triunfa al volver a llamar al hombre.

En el agregado final a la catequesis, después de decir a los extraviados respecto a la gracia del bautismo, que al no cambiar su vida, al no mostrarse verdaderamente como hijos de Dios, nacen solo en apariencia (202), finaliza el escrito volviendo a lo indecible que son tanto los bienes propuestos como la vida dolorosa de los pecadores, resultados correspondientes a nuestra libertad según el justo juicio de Dios, después de esta vida (203). Porque nuestra naturaleza, según el plan de su

(192) Dios es la verdadera virtud (XV, 45, 11).

(193) Cf. VII, 27, 9-28, 18.

(194) Los órganos de la generación, que conservan la inmortalidad para la humanidad, en cierto sentido la vuelven ineficaz (XXVIII, 72, 8-14).

(195) Si hubiere conservado el ‘según la imagen’ en esta vida (texto dudoso).

(196) La mortalidad ciñe económicamente a la naturaleza creada para la inmortalidad. Es provisoria.

(197) Cf. VIII, 29, 1-31, 21. Por la inefable mezcla de Dios con la parte sensible y con la parte

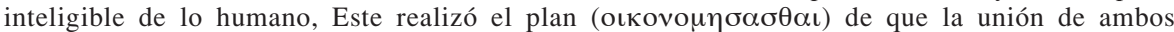
permaneciera para siempre (cf. XVI, 48, 4-21). Es un retorno a la gracia primera, a la vida eterna, escurrida la maldad por la disolución de la muerte.

(198) XXXV, 88, 13-18. Cf. Ib., 88, 21-89, 1

(199) Cf. VIII, 32, 4-33, 22.

(200) Cf. VIII, 34, 2-17.

(201) VIII, 36, 8-16.

(202) Cf. XL, 102, 4-105, 9.

(203) XL, 105, 11-106, 15. El fuego que no se extingue y el gusano que no termina, muestran que ambos son de otra naturaleza, diferente de lo que conocemos. 
organizador, se encamina necesariamente hacia la replasmación y reconstitución de nuestro compuesto, haya recibido o no la gracia del bautismo. Pero los no purificados lo serán por el fuego, durante largos siglos, antes de ser devueltos a Dios sanos y salvos. Porque nadie llega a ser del coro divino, si no está purificado de toda maldad (204). En el restablecimiento ( $\alpha \pi \circ \alpha \alpha \tau \alpha \sigma \tau \alpha \sigma \iota \varsigma)$ (205) de su prístina condición, de los que ahora yacen en la maldad, se alzará al unísono la acción de gracias de parte de toda la creación, de los castigados en la purificación y de los que no la necesitaron (206). Hasta el adversario la encontraría justa y salvadora, si ahora llegara a percibir el beneficio (207). Dios, engañando al engañador, no solo hizo el bien a la humanidad, sino al mismo adversario que obró contra nosotros la perdición. Ante la vida, desaparece la muerte, etc. (208) Aunque la purificación sea dolorosa, Dios libera al hombre de la maldad y cura al mismo inventor de esta (209). Así Gregorio nos ha anunciado la esplendente victoria de la bondad de Dios sobre el mal, la apocatástasis, pero en forma pedagógica, es decir, amenazando con gravísimos castigos.

Dejando para después el nacimiento, muerte y resurrección de Cristo, aspecto central de la economía de Dios y de esta obra, vayamos ahora a otros aspectos de la confrontación con el mal, en que se objeta la economía. Es de advertir que los objetantes ahora pueden ser griegos y judíos, como decíamos al comienzo, y no necesariamente los dualistas, contra los que iba de frente la respuesta al problema del mal en V-VIII. La primera de estas objeciones es por qué Dios difirió tanto tiempo este gran beneficio de nuestra salvación. ¿Por qué no cortó la maldad en sus comienzos, antes de que se propagara? Por sabiduría y previsión. Como en las enfermedades corporales hay que esperar que el humor corrupto salga todo afuera para entonces aplicarle la cura directamente, así el médico del universo esperó a que ninguna forma de maldad quedase escondida dentro de la naturaleza. Se puso a curar la enfermedad cuando esta había madurado, culminado, para así alcanzarla toda (210). La segunda objeción pregunta por qué la vida humana sigue todavía a merced de los pecados, después que se aplicó la curación. Gregorio responde a esto, que la maldad, golpeada mortalmente, sigue aún perturbando con lo que le queda, como la cola de la serpiente, muerta la cabeza (211). Entonces pasan a la tercera objeción. ¿Por qué la gracia de la fe no ha llegado a todos los hombres? O Dios no quiere repartir copiosamente a todos su beneficio, o no puede hacerlo. Responde Gregorio diciendo que Dios dirige a todos por igual su llamado. Por tanto, la acusación se traslada a los que no se han dejado conducir a la fe. Porque Dios, en un exceso de estima por el hombre, dejó que esto estuviese bajo nuestra libre disposición. Pero, replican, Dios podría arrastrar forzadamente a aceptar el mensaje a los que se resisten. Responde Gregorio que ser arrastrado así es propio de los irracionales. Sin

(204) XXXV, 91, 5-XXXVI, 92, 11.

(205) Véase también XXXV, 91, 5-12.

(206) XXVI, 67, 9-13.

(207) XXVI, 66, 22-67, 2.

(208) XXVI, 66, 4-10.

(209) XXVI, 67, 18-21. Véase $I b ., 66,18-67,2$.

(210) XXIX, 72, 16-73, 9; XXIX, 73, 20-74, 4.

(211) XXX, 74, 5-14 
libertad, ha desaparecido la virtud, la vida ha perdido su valor; se ha eliminado la alabanza de los que llevan una vida recta. Concluye que no es a la bondad divina a quien hay que acusar de esto (212). Resumiendo finalmente, insiste en que por la bondad de Dios el hombre fue creado para participar de esa bondad (de los bienes divinos), y por bondad de Dios fue salvado. En esa línea, también ha desvirtuado los argumentos contra esa bondad, provenientes del mal.

\section{NACIMIENTO Y MUERTE NO SON INDIGNOS DE DIOS}

"Jesús Cristo" solo es usado en la cita referente a Flp 2, 10 (213); "Cristo", en cambio, otras 5 veces (214). Así XVIII, 52, 4 se refiere a la teofanía de Cristo, en los tiempos en que Jerusalén y el culto judío resplandecían. Respecto a la encarna-

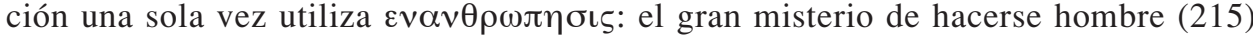
Pasemos revista a múltiples expresiones que usa Gregorio al respecto. Como ya dijimos, rara vez habla del Logos en referencia a ella. Comienza hablando de la

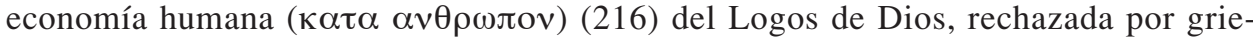
gos y judíos como increíble e inconveniente respecto a Dios (217). Después se referirá a la economía del misterio (218) de haber nacido Dios en el hombre (219). Es la manifestación (220) de Dios (221) en carne (222) y por la carne (223). Es la $\pi \alpha \rho o v \sigma \iota \alpha$ de Dios entre los hombres (224). El Logos plantó su tienda en la carne (225). Inhabitó en un cuerpo, transformándolo y elevándolo ( $\mu \varepsilon \tau \varepsilon \pi o ı \eta \theta \eta)$ a la dignidad divina (226). La naturaleza omnipotente descendió a la bajeza de la humanidad (227). Pero pese a que lo alto llega a ser ( $\gamma \varepsilon v o u \varepsilon v o v)$ en la bajeza y ahí es contemplado, sin embargo no baja de la altura. La divinidad se enlaza ( $\sigma \cup \mu \pi \lambda \alpha \kappa \varepsilon \iota-$ $\sigma \alpha)$ (228) con la naturaleza humana y se hace eso, pero sigue siendo aquello (229).

(212) Cf. XXX, 74, 14-XXXI, 77, 6.

(213) XXXII, 81, 3. Ante Él se doblará toda rodilla.

(214) XIII, 41, 23; XVIII, 51, 16; 52, 4; XXXVII, 95, 26; XXXIX, 99, 18

(215) XXVI, 67, $14 \mathrm{s.}$

(216) Véase también XX, 54, 1; 55, 1s.

(217) V, 15, 17-20. La palabra оєкоvоuı $\alpha$ se referiría a la encarnación y muerte (XVI, 49, 9; XXXII, 79,21 ), al menos unas 15 veces (incluida alguna referencia al bautismo). Véase XVI, 48, 6-9.

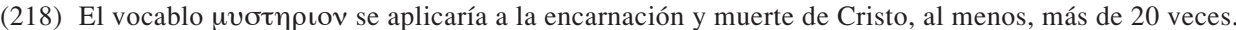

(219) XXV, 64, 1s. Cf. XXVIII, 71, 9

(220) Se utiliza $\phi \alpha \iota v \omega$ y compuestos, y substantivos correspondientes.

(221) Cf. XII, 40, 16; XIII, 41, 21; XVIII, 51, 5s ( $\chi \alpha \rho \iota \varsigma)$; 52, 4.11s.15 ( $\chi \alpha \rho \iota \varsigma)$; XXXVII, 97, 21s. Véase XXIII, 60, 17; XXIV, 62, 5s; XXXII, 79, 6-8

(222) XII, 40, 6s; XXXIV, 84, 11

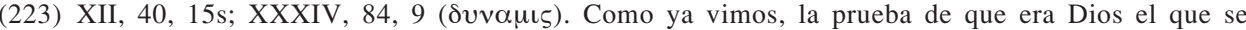
manifestaba, son los milagros.

(224) XV, 43, 17s. Cf. XVIII, 50, 19; XIX, 52, 24-53, 1; XXIV, 62, 5; XXV, 64, 4. Véase XV, 43, 23; 44, 1s; XVIII, 52, 3; XXVIII, 71, 13.15

(225) XXXVII, 97, 2.

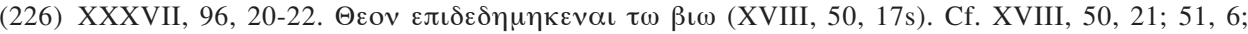

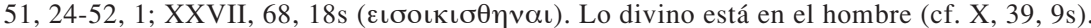

(227) XXIV, 61, 4-6. Cf. XXIV, 61, 13-15.25-27. Esto muestra una sobreabundancia de poder. Véase

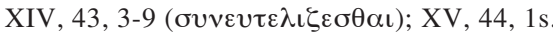

(228) Véase también XIX, 53, 3; XXVII, 69, 2-4; 70, 13s

(229) XXIV, 61, 26-62, 3. Su firmeza en el bien y su naturaleza inmutable no se vieron afectadas por la versatilidad de la libertad humana (XX, 54, 5-7). 
Dios ha nacido $(\gamma \varepsilon \gamma \varepsilon v \eta \sigma \theta \alpha \mathrm{l})$ en naturaleza de hombre (230). El Logos de Dios, siendo Dios y Logos, se mezcló a la naturaleza humana y entró ( $\gamma \varepsilon v o \mu \varepsilon v o \varsigma$ ) en nuestro cuerpo, que, como corresponde, se alimentaba con pan (231). Dios ha

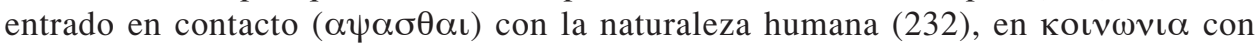
el hombre (233). Participa de la humanidad (234). En X, 39, 6s, el $\pi \rho o \sigma \varepsilon \gamma \gamma \iota \sigma \mu o v$ a lo humano va junto con $\varepsilon v \omega \sigma \iota v \tau \iota v \alpha$ (235). Pero la divinidad no queda circunscrita por la carne, como tampoco lo está el alma, según Gregorio (236).

Para expresar la unión, a menudo utiliza el vocabulario de la mezcla (237) de la divinidad con lo humano (238). Ahora está mezclado a nosotros en cuanto que mantiene la naturaleza en el ser, entonces, en cambio, se mezcló a lo nuestro para que lo nuestro, por esta mezcla con lo divino, llegara a ser divino, arrancado a la muerte y liberado de la tiranía del adversario (239). El Dios, que se ha manifestado, por esto se mezcló Él mismo a una naturaleza perecedera, para que lo humano, por la comunión con la divinidad, fuera juntamente divinizado; y mediante su carne se mezcla a los cuerpos de los que han creído para que también el hombre, por la unión

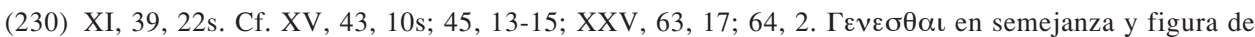
hombre según la bajeza de nuestra naturaleza, de los que estamos sometidos a la muerte. Llegado a serlo, obró lo propio de Él, conforme a su naturaleza (XXIV, 63, 4-9). Véase XXXII, 77, 17-21. Decimos que Dios $\gamma \varepsilon \gamma \varepsilon v \eta \sigma \theta \alpha$ en ambos cambios de nuestra naturaleza, por el que el alma se une

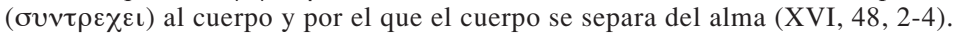

(231) XXXVII, 96, 7-12 ( $\gamma \varepsilon v o u \varepsilon v o s$ en nuestro cuerpo). Cf. XXVI, 67, 15-18.

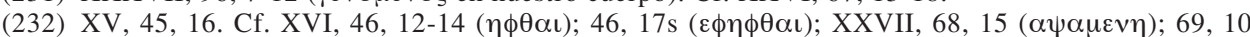

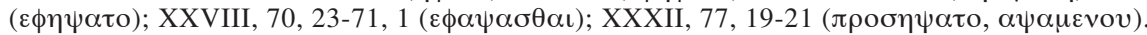

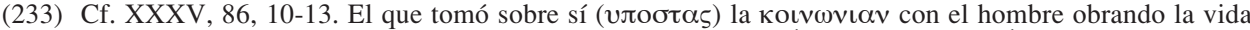
en forma efectiva, para que, a través de la carne asumida por Él y deificada con Él, fuera salvado todo cuanto era afín a la carne y de la misma especie. Según XXXII, 78, 1s, el que existe eternamente tomó

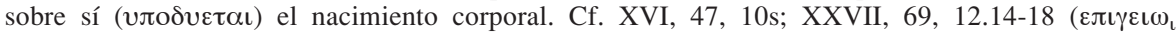

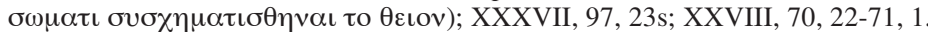

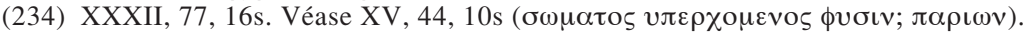

(235) En su carne la potencia superior se aproxima ( $\pi \rho 0 \sigma \varepsilon \gamma \gamma \iota \sigma \mu \circ \varsigma)$ al adversario (XXIII, 60, 8-10). El vocablo $\varepsilon v \omega \sigma \iota \varsigma$, que aparece 9 veces, es usado normalmente respecto a la unión del alma y el cuerpo, especialmente en torno a la resurrección. Véase también XI, 39, 13s; XVI, 48, 8s.25s. El alma no está encerrada en los límites del cuerpo (X, 38, 9-20). Pero hay una ovuфvı $\alpha$ del alma respecto a la carne (XI, 39, 12s)

(236) Cf. X

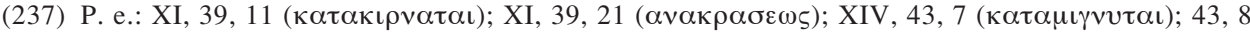

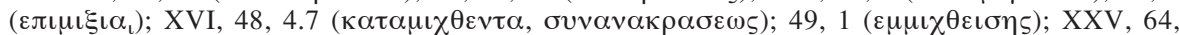

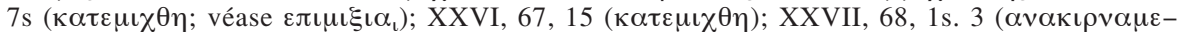

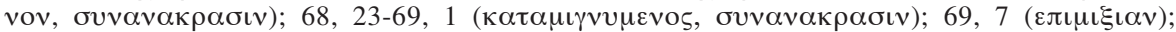

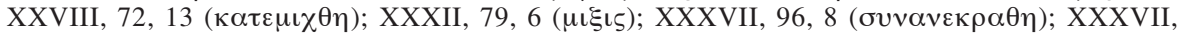

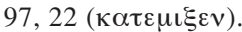

Gregorio, por ejemplo, también usa vocabulario de mezcla para la unión de alma y cuerpo (inteligible y sensible) (VI, 21, 22-22, 1.7s.10s; X, 38, 18s; XVI, 48, 49, 2s; XXXVII, 93, 1s), y para la unión entre la naturaleza humana y el mal (VI, 26, 3s; VIII, 29, 13-16; 31, 18-20 (el cuerpo); IX, 37, 14-16; XVI, 48, 18; XXVI, 67, 8s; XXXV, 88, 17s; 88, 23-89, 1.5-7; 92, 1-3; véase VIII, 31, 16; 33, 14s; XXVI, 66, 10s; XXXVII, 94, 1s). La naturaleza humana está mezclada con algo pariente de lo divino (V, 17, 14-16; cf. VI, 22, 17s; 23, 4s) para que tenga un impulso hacia allá. El alma, por medio de la fe, se mezcla con el guía de nuestra salvación; el cuerpo, en cambio, de otra forma llega a estar en participación y mezcla con el Salvador (cf. XXXVII, 93, 4-8; véase XXXVII, 98, 3s). Véase XXV, 64, 6s.

(238) En XX, 53, 3-5, dice que la divinidad no quiso salvar lo humano por decreto, sino por sí misma, entrelazándose con lo nuestro. Véase XXIV, 62, 17s.

(239) XXV, 64, 6-10. 
( $\varepsilon \nu \omega \sigma \varepsilon \iota)$ con lo inmortal, llegara a ser participante de la incorruptibilidad (240). Se mezcló con lo sensible y con lo inteligible del compuesto humano; así, mediante esta indecible mezcla, realizó el plan de que la unión ( $\varepsilon v \omega \sigma \iota \varsigma)$, de lo una vez unido (cuerpo y alma), permaneciera para siempre (241). Era del todo lógico que el que se mezcla con nuestra naturaleza recibiera la mezcla con nosotros a través de todas las propiedades de ella (242). Pasó a través de todas las propiedades de la naturaleza: nacimiento, educación, crecimiento, y hasta la prueba de la muerte (243).

Otras expresiones de la Encarnación presentan la divinidad envuelta, ocultada, por su carne, por la naturaleza humana, para que así el adversario no se asuste, sino

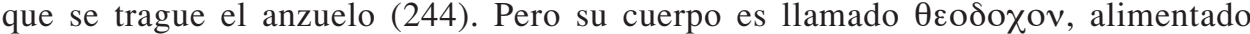

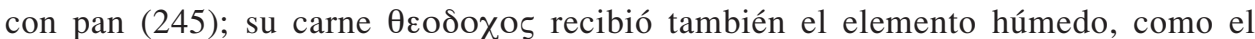

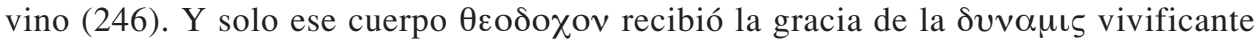
(247), y al introducirse en el nuestro, mediante la comida y la bebida, transforma el nuestro, por entero, en sí mismo, en su propia naturaleza (248). Creemos que el pan, ahora santificado por el Logos de Dios, se transforma en el cuerpo del Logos de Dios (249), habiendo sido dicho por el mismo Logos: esto es mi cuerpo (250). La gracia del Logos santificaba allí el cuerpo, cuya consistencia venía del pan; aquí igualmente el pan es santificado por el Logos de Dios y la plegaria (251). El hombre $\theta \varepsilon o \delta o \chi 0 \varsigma$, que por la resurrección fue elevado junto con la divinidad, era de nuestra pasta; por eso, su resurrección se extiende a todos (252). En el hombre asumido por Él (253), después de la disolución, retornó de nuevo el alma al cuerpo (254). Aquel hombre de arriba, asumiendo la $v \varepsilon \kappa \rho о \tau \eta \tau \alpha$, después de ser depositado bajo tierra, al tercer día surgió de nuevo a la vida (255).

(240) XXXVII, 97, 21-98, 6. La comunión eucarística prolonga la línea de la Encarnación.

(241) XVI, 48, 4-9.

(242) XXVII, 68, $1-3$

(243) XXVI, 67, 15-18. Cf. XXXII, 77, 16-21. Véase IX, 36, 21-37, 2; 37, 18-21; XIII, 42, 4-5 (en sentido contrario); XVI, 48, 2-4; XXVII, 68, 1-3.14-17; 69, 14-17. Se mezcló a la ßıos humana por los mismos caminos por los que la naturaleza combate a la muerte (XXVIII, 72, 13s), es decir, por el nacimiento. Véase XV, 44, 10-16 (pasando sucesivamente por todas las edades, etc.); XVII, 49, 23-25.

(244) Cf. XXIII, 60, 5-17; XXIV, 62, 4-10; XXVI, 64, 16-20.

(245) XXXVII, 96, 16s. En cierto sentido, Él mismo era pan.

(246) XXXVII, 97, 20s. Este se convierte en sangre (XXXVII, 97, 16-20).

(247) XXXVII, 94, 8-10.

(248) XXXVII, 93, 21-94, 12. El cuerpo de Jesús fue inmortalizado por Dios. Y nuestro cuerpo, por la comunión con lo inmortal, pasa a participar de la incorruptibilidad.

(249) XXXVII, 96, 22s. Véase $I b ., 97,10-11$.

(250) XXXVII, 97, 11s.

(251) XXXVII, 97, 3-9. Entonces el pan transformado en aquel cuerpo se cambió a potencia divina. Cf. XXXVII, 96, 20-97, 2.

(252) Cf. XXXII, 78, 7-17. Insinúa que en la resurrección culmina la divinización del cuerpo de Cristo (cf. Winling, Babel, ad 1. c.). Según B. Pottier (Dieu et le Christ selon Grégoire de Nysse. Etude systématique du 'Contre Eunome' avec traduction inédite des extraits d'Eunome, Namur 1994, p. 251), no hay progreso en la unión sino progresiva extensión de esta a la totalidad de la naturaleza humana de Cristo.

(253) Véase también XXXII, 77, 23s; XXXV, 86, 11-13.

(254) XVI, 49, 4-6. Como para constituir un punto de partida para la resurrección de toda la naturaleza humana (cf, XVI, 49, 6-16).

(255) XXXV, 88, 5-8. 
Hasta aquí, sin pretender ser exhaustivo, diversas formas en que Gregorio expresa la Encarnación. Queda claro que la unión de Dios es con una naturaleza humana íntegra, es decir, compuesta de cuerpo y alma. El cuerpo, cuya bondad se defiende, recibe un énfasis especial del cuerpo de Cristo que comulgamos. Existe un rico paralelismo entre el cuerpo de Cristo (256) santificado y deificado por el Logos, cuerpo que es pan asimilado, y el pan que se comulga, transformado por la bendición del Logos en cuerpo de Cristo, como Él mismo lo declara. El alma también tiene un gran papel en la muerte y resurrección de Cristo. La muerte, en efecto, consiste en la separación del alma y del cuerpo, permaneciendo la divinidad unida a ambos (257). En la resurrección, en cambio, comienzo de la nuestra, el Logos vuelve a juntar a ambos para siempre, quedando el cuerpo de Cristo inmortalizado. Así la muerte, que era pasajera, ha quedado definitivamente vencida, según la economía divina. Pero, más allá de esto, el alma de Cristo no juega ningún papel en nuestra redención, p. e. no se habla de la obediencia de Cristo ni de su oblación al Padre, etc. La cristología, pues, se ha entrelazado con la concepción del hombre como unión de cuerpo y alma, de sensible e inteligible, reforzándose mutuamente. Lo humano no es malo en sí y la Encarnación no es indigna de Dios. El hombre era central en la armonía de la creación, para que todo participe de Dios.

Bajo el punto de vista de la terminología, más se habla de lo humano que de la carne, superándose así las posibles estrecheces de una cristología $\Lambda$ oүo $-\sigma \alpha \rho \xi$, que precisamente había conducido a la herejía de Apolinar. Pero al hablar del hombre, a menudo recurre a expresiones como naturaleza humana, lo nuestro, que no tienden

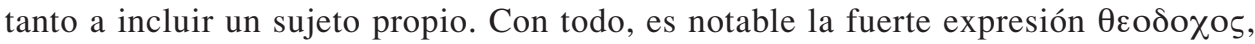
que una vez aplica al hombre. También se habla de asumir, inhabitar (lenguaje que será de preferencia antioqueno), y a menudo de naturaleza humana (258). En Cristo hay que ver lo humano y considerar lo divino, porque en el Evangelio se manifiesta una mezcla de lo divino con lo humano en todo, produciéndose la voz y los hechos humanamente y lo pensado según el sentido oculto manifestando lo divino (259). La divinidad no baja, permanece lo que es, y obra lo propio (260). Cristo pasa por todas las propiedades de la naturaleza humana, como el nacimiento y la muerte (261). Pero, por otro lado, usa abundantemente el vocabulario de mezcla para expresar la unión. Todavía falta un tiempo para la $\varepsilon v \omega \sigma \iota \varsigma \alpha \sigma v \gamma \chi v \tau o \varsigma$ de Calcedonia. Pese a la imperfección del vocabulario, es evidente la integridad de lo humano, y que todo se atribuye al mismo sujeto, como se ve en la comunicación de idiomas, cuando habla,

(256) Varias veces habla del cuerpo de Cristo.

(257) Así lo insinúa en XVI, 48, 24-49, 1.

(258) Respecto a la naturaleza humana de Cristo, véase p. e.: XI, 39, 22s; XV, 45, 12s; XVI, 48, 2-4.9. 11; XVIII, 51, 5s; XXIV, 61, 25s; 62, 2s.7s; 63, 4-9; XXV, 63, 17; XXVI, 64, 16s; XXVII, 70, 13s; XXXVII, 96, 7-12; 97, 21-23. Pero nunca expresamente y en forma conjunta habla de las dos

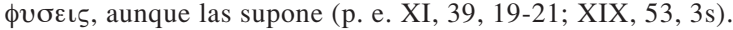
Además expresa que ese hombre es Dios (cf. p. e. XIII, 42, 11-13).

(259) XXXII, 79, 3-12. Por eso, hay que ver en la muerte lo humano, y en el modo de ella investigar lo más divino. Según XXXII, 81, 18-20, el Jesús resucitado asciende al cielo según lo que aparece, pero está en todas partes (cf. también XXXIV, 86, 2-5) según lo que se piensa. Cf. XXIV, 61, 2662,3 . Por la envoltura de su cuerpo, la potencia divina se hizo $\chi \omega \rho \eta \tau \eta$ para el adversario (XXIII, 60, 14-16; cf. Ib., 21-23)

(260) No está circunscrita por el cuerpo.

(261) Según XXXIV, 84, 14s, la propiedad de cada ser da a conocer su naturaleza. 
por ejemplo, del cuerpo del Logos de Dios (262). Pero la no actividad del alma y el estar centrado en la economía que Dios realiza, manifiesta una cristología descendente, en la que el hombre resulta divinizado. Recordemos que su centro es el Dios razonable. En lo recién sintetizado están las bases de nuestra redención.

Pero la Encarnación es un misterio que supera la razón humana. Si no entendemos el modo como se une el alma con el cuerpo, tampoco comprenderemos la mezcla de lo divino con lo humano. Es superior al curso de nuestros razonamientos (263). Aunque los ejemplos no valen en todos los puntos (264), nos ayudan para alguna conjetura sobre la economía. La unión en Cristo tiene algún parecido con la unión de la llama y la materia que la alimenta. Forman una sola cosa, siendo inseparables; sin embargo, la razón las distingue. Así como la materia no encierra a la llama, tampoco la divinidad está circunscrita por el hombre (265).

Hecha esta introducción sobre las expresiones de la Encarnación, pasemos ahora a la polémica sobre lo $\theta \varepsilon 0 \pi \rho \varepsilon \pi \varepsilon \varsigma$ de esta. En XIX, 52, 23-53, 2, son nombrados como interlocutores los helenizantes y los judíos. En IX, 36, 17-37, 7 afirma Gregorio que hasta aquí (la Trinidad y que Dios no es el causante del mal) podrá quizás estar de acuerdo el que mire a la consecuencia lógica, porque nada de lo dicho parece ser una concepción indigna de Dios. Pero no así respecto a lo que sigue: nacimiento humano, crecimiento desde la infancia hasta la madurez, comida, bebida, cansancio, sueño, aflicción, lágrimas, falsa acusación y tribunal, cruz, muerte y entierro en la tumba. En cierta manera esto embota la fe de las almas apocadas, hasta el punto de no admitir la resurrección por lo indigno de la muerte. Replica, empero, nuestro autor, estas cosas no son malas, por tanto tampoco vergonzosas, sino buenas y, por consiguiente, dignas de Dios (266). A la objeción, recién vista, de que la divinidad estaría circunscrita por la naturaleza humana, responde nuestro autor que no lo está y, por tanto, en el contacto de la naturaleza divina con lo humano se salvaguarda un pensamiento digno de Dios (267). A la pregunta de cómo se mezcla la divinidad con lo humano, responde que esto supera nuestra comprensión, pero que no dudamos, por los milagros narrados, que Dios haya nacido en naturaleza de hombre (268). Ciertamente el nacimiento y la muerte son propios de la naturaleza carnal. Pero lo que en este caso precede al nacimiento y lo que sigue a la muerte, no tienen nada en común con nuestra naturaleza, porque su nacimiento no comienza desde un $\pi \alpha \theta$ os (placer) ni termina en un $\pi \alpha \theta 0 \varsigma$ (corrupción) (269). Porque si el kerygma contuviera un engendrar por la unión de dos personas y la

(262) Entre otros muchos ejemplos, puede citarse XXXV, 90, 2-5.

(263) Cf. XI, 39, 11-40, 6. Esto implicaría una comparación entre la unión del alma con el cuerpo y la unión de Dios y lo humano en Cristo (véase también X, 38, 5-23). Tampoco comprendemos cómo ( $\tau 0 \pi 0 \theta \varepsilon \vee \eta \tau 0 \pi \omega \varsigma)$ toda la creación toma su existencia de la naturaleza increada.

(264) En este no hay que pensar en la naturaleza destructora del fuego.

(265) X, 38, 20-39, 10. Algunos Padres verán un ejemplo en la zarza ardiendo de Ex.

(266) IX, 37, 7-38, 4. Lo único vergonzoso es el $\pi \alpha \theta$ os según maldad $(I b ., 37,12 s)$.

(267) X, 38, 5-39, 10 .

(268) Cf. XI, 39, 11-XII, 41, 8.

(269) Cf. XIII, 41, 9-18; 42, 5-8 (difiere por el $\tau \rho o \pi$ $\varsigma$ del nacimiento, etc.); 42, 17-22. Por tanto, es Dios. Porque si concedes por los relatos su nacimiento, por los mismos concederás también que fue de una virgen y que resucitó (XIII, 42, 8-43, 2, etc.). Concluye que no está del todo dentro de la naturaleza, porque nace por sobre ella. Respecto al término $\pi \alpha \theta$ os, véase lo ya dicho al respecto a propósito de lo que es el mal. 
corrupción después de la muerte, propiedades de nuestra naturaleza, el interlocutor creería que de ninguna manera es Dios (270).

¿Cuál es la causa, dicen, de que el ser infinito se mezcle con la impureza de la naturaleza humana, de modo que sus actividades sublimes se deprecien? Gregorio tiene una respuesta digna de Dios: la filantropía, característica de la naturaleza divina. Porque nuestra naturaleza necesitaba de alguien que la sanara, levantara, vivificara, recondujera al bien; necesitaba de la luz, de redentor, defensor, liberador (271). Pero objetan que Dios podría salvar al hombre (272) por simple decreto, permaneciendo impasible en las alturas de su gloria divina, sin tener que nacer, pasar por todas las sucesivas edades, experimentar la muerte y, así, mediante la resurrección de su propio cuerpo alcanzar su objetivo (273). Responde Gregorio que solo la maldad se opone a la virtud. Si dijera que la divinidad nació en la maldad, razón tendría el contrincante. Sería indigno y vergonzoso. Pero Dios no nace en la maldad sino en naturaleza de hombre. Porque nada propio de la esencia humana se opone a la virtud (274). Pero replican que el mismo cambio de nuestro cuerpo es $\pi \alpha \theta$ o, y Dios es impasible. Nuestro autor contesta que esto es $\pi \alpha \theta$ o $\varsigma$ en sentido impropio. Porque todo movimiento continuado de la naturaleza según su propia concatenación, como el nacimiento, la permanencia del sujeto mediante la ingestión y evacuación del alimento, la disolución del compuesto y tránsito a elementos afines, es más propiamente acción que $\pi \alpha \theta$ os. Así lo divino solo entró en contacto con el movimiento según la naturaleza, cuyo origen y subsistencia tuvo en Él su principio. En esto no hay nada indigno de Dios. Respecto a la pasión propiamente dicha, fue como el médico que cura el $\pi \alpha \theta$ os, pero permanece fuera de él. Si la mutación del nacimiento no es $\pi \alpha \theta$ os, tampoco lo es la muerte. Dios, pasando ( $\gamma \varepsilon \gamma \varepsilon v \eta \sigma \theta \alpha \iota)$ por las dos mutaciones, mezclado a lo sensible y a lo inteligible cumplió su plan: que cuerpo y alma permanecieran unidos para siempre (resurrección) (275).

(270) XIII, 42, 2-5. En núm. XVI, después de haber distinguido el simple movimiento de nacer o de la disolución del compuesto y tránsito a elementos afines, del $\pi \alpha \theta$ o s propiamente dicho (cambio de la virtud a la maldad) (46, 2-12), afirma que el $\pi \alpha \theta$ os según placer que está al origen del nacimiento y el impulso de los vivientes hacia la maldad son $\alpha \rho \rho \omega \sigma \tau \eta \mu \alpha$ de nuestra naturaleza. Pero aquí el nacimiento ha sido ajeno a la $\rceil \delta o v \eta$, por tanto, Dios no ha participado del $\pi \alpha \theta$ os en sentido propio (47, 4-11). Por lo demás en el resto de esta obra, salvo en VI, 24, 14s, la $\eta \delta o v \eta$ siempre va referida al modo como el adversario engaña al hombre y a la caída de este. Pero en XXVIII, 71, 19-72, 14, contra la objeción sobre el modo de nacer, muestra Gregorio la dignidad de los órganos de la generación, que en cierto sentido vuelven ineficaz la muerte. Y concluye que no hay indignidad en que Dios se haya mezclado con la vida humana, mediante los procedimientos con que la naturaleza lucha contra la muerte.

Respecto a la corrupción dice en VIII. 30, 20-31, 21, que la disolución de lo sensible es el disolverse de nuevo en los elementos del cosmos, de los que había sido constituido (véase también XVI, 46, 10-12). No es vuelta a la nada, no es perecer, aunque no lo podamos captar con nuestra sensibilidad. Mediante la resurrección la vasija será remodelada. En conclusión, no me parece del todo coherente su pensamiento en esta materia, sobre todo respecto a la corrupción, salvo que esté también considerando el horror del interlocutor.

(271) XIV, 43, 3-XV, 43, 25.

(272) Arrancarlo del poder del enemigo y devolverlo al estado inicial.

(273) XV, 44, 4-16. Cf. XVII, 49, 19-50, 1

(274) Cf. XV, 44, 21-45, 21. Véase, p. e. XXVII, 69, 12-14.

(275) XVI, 45, 22-48, 9. 
El interlocutor insistirá. Si Dios tiene tanto poder (276), ¿por qué no realiza nuestra salvación con un solo acto de su voluntad? Responde Gregorio que no toca a los enfermos prescribir a los médicos la forma del tratamiento, sino recibir agradecidos el beneficio. En el presente, la utilidad de lo que realiza la pletórica bondad de Dios permanece oculta (277); solo se la ve por la fe. Y a los que buscan sabiduría respecto al poder de Dios, contesta nuestro autor con el testimonio de los hechos. Así se desvaneció el engaño de los demonios mediante los ídolos y se instauró en toda la tierra el sacerdocio incruento de los cristianos y su excelsa filosofía, despreciando los mártires la muerte. Así no quedan huellas del templo judío y estos no tienen acceso a su lugar santo (278). Con todo, a los helenizantes y expositores de las doctrinas judaicas, estos hechos no les parecen pruebas de la venida divina. Recurrirá entonces Gregorio a las ideas piadosas que se tienen sobre Dios para mostrar por qué la divina naturaleza se unió con la nuestra para salvar por sí misma (279) lo humano, en vez de proceder por simple decreto (280). Pero esto nos lleva a la sección siguiente de este trabajo.

\section{ECONOMÍA (281) NO SOLO PODEROSA, SINO A LA VEZ JUSTA, BUE- NA Y SABIA}

Al tratar de Dios y su creatura, hice una referencia general a las numerosas veces en que estos atributos son referidos a Dios y su acción, a que los cuatro siempre deben ir juntos en la economía para no dejar de ser virtudes. Ahora veremos su aplicación. Respecto a la bondad de Dios, confrontada al mal del hombre, hablé en sección aparte. Retomemos ahora el hilo del argumento que exponía. Según Gregorio, todos están de acuerdo en estos cuatro atributos de lo divino. Y en la economía no se puede manifestar alguno de ellos sin los otros. Porque ninguno de ellos en sí mismo, separado de los demás, es virtud. Por ejemplo, el poder, separado de la justicia y sabiduría, sería brutal y tiránico. Buscamos en Dios, ante todo, los signos de su bondad. Esta es evidente, porque por ella vino a salvarnos (282). Pero la bondad de la intención no aprovecha, si no va acompañada de la sabiduría, para sanar al paciente (283). Con todo, la sabiduría únicamente es virtud, si va asociada a la justicia (284). En el núm. XXI nos recuerda la voluntaria caída del hombre, engañado por el enemigo. Dios, porque es bueno, se compadece del hombre caído, y porque es sabio, no desconoce el modo de restablecerlo (285).

(276) Por lo dicho, tiene en sus manos la destrucción de la muerte y la entrada de la vida.

(277) No se la observa distintamente.

(278) Vieron al esperado, sobre el que previamente habían sido instruidos por los profetas y la ley, pero observando la letra de la ley, no acogieron la gracia que se había manifestado (XVIII, 52, 9-15).

(279) Véase también XXIV, 62, 16-18.

(280) Cf. XVII, 49, 17-XIX, 53, 8.

(281) Respecto a la soteriología de Gregorio, puede consultarse, Winling, op. cit., 79-98.

(282) Aunque el hombre se había pasado el enemigo.

(283) Los hechos, por su concatenación y orden que acompaña, muestran lo sabio y hábil ( $\tau \varepsilon \chi v \iota \kappa o v)$ de la economía (XX, 54, 19-22).

(284) Cf. XX.

(285) XXI, 57, 6-8. 
¿En qué estuvo lo justo? En que Dios no usó un tiránico poder absoluto contra el que retenía al hombre, sino que le concedía, a cambio, tomar todo el rescate que este quisiere (286). Y el dueño, para una mayor satisfacción de su orgullo, quiso tomar lo más valioso. Escogió a Jesús, cuyas maravillas observaba. La divinidad, para no aterrarlo, se revistió de carne. Así el enemigo contemplaba en Él, parte de esa carne que ya tenía subyugada. Por lo tanto, el haber Dios elegido salvar, atestigua su bondad; el haber dado al rescate carácter de contrato, muestra su justicia; y el haber hecho $\chi \omega \rho \eta \tau o v$ para el enemigo lo que no lo era, prueba su sabiduría (287). Pero entonces, ¿dónde está el poder de la divinidad? Está mezclado con la filantropía. El descenso a nuestra pequeñez demuestra el poder, mucho más que los milagros, la creación y providencia sobre los seres. Es la sobreabundancia del poder que no haya ningún obstáculo en las condiciones contrarias a su naturaleza. Viene a lo humilde sin rebajarse en su altura, la divinidad se abraza a la naturaleza humana y se hace esta, permaneciendo aquello (que era). Lo divino, pues, se escondió en la envoltura de nuestra naturaleza para que el adversario, con el cebo de la carne, se tragara el anzuelo de la divinidad. Y así la vida instalada en la muerte, y la luz brillando en la oscuridad, hacen desaparecer a sus contrarios. En resumen, la bondad se capta en elegir salvar al perdido; la sabiduría y la justicia, en el modo; el poder, en el hecho de llegar a ser en semejanza y en figura de hombre (conforme a la pequeñez de nuestra naturaleza), del que se podía esperar que sería sometido a la muerte, y obrar, sin embargo, conforme a su naturaleza (divina): el desvanecimiento de las tinieblas y la destrucción de la muerte (288).

Si Dios está en todas las cosas (todos los seres dependen del que es) y no es exterior al hombre, ¿por qué avergonzarse de que haya nacido en un hombre? Pero su presencia no es de la misma manera. Ahora está mezclado con nosotros manteniendo la naturaleza en la existencia; entonces, sin embargo, se mezcló con lo nuestro para que lo nuestro, gracias a la mezcla, llegara a ser divino, después de arrancarnos de la muerte y liberarnos del adversario. Su surgir de la muerte es principio del nuestro para vida inmortal (289).

Alguien puede considerar que Dios se valió de un cierto engaño al ocultarse bajo la naturaleza humana, no siendo reconocido al ponerse en las manos del dueño de los hombres. Pero, el dar su merecido al engañador, a su vez engañado, muestra su justicia (290), sin salirse sabiamente de la bondad de la finalidad en la filantropía. Y Dios usa esta invención engañosa para salvación. Así hizo el bien no solo al que había perecido, sino también al mismo que lo había hecho perecer. El aproximarse de la vida, luz e incorrupción genera la desaparición de lo contrario (291). Cuando suceda la apocatástasis de lo originario, se elevará al unísono una acción de

(286) XXII. Así no dejaba un pretexto al adversario para una contestación jurídica. Porque el hombre mismo se había esclavizado vendiendo su libertad.

(287) Cf. XXIII.

(288) Cf. XXIV.

(289) XXV.

(290) El engañador recibe lo correspondiente a las semillas plantadas por su propia libertad.

(291) Cf. XXVI, 64, 13-66, 10. La potencia divina, a modo de fuego, destruye todo lo que es contrario a la naturaleza, purificando, por más penosa que sea la separación (XXVI, 66, 20-22). 
gracias de parte de toda la creación. Así mediante la mezcla con la humanidad, Dios libera al hombre y sana al mismo inventor de la maldad (292).

Despejado el problema de la justicia, que afecta al trato con el adversario, nuestro autor vuelve a lo indigno, para el interlocutor, del nacimiento y muerte. Pero aceptar todas las particularidades ( $\llcorner\iota \omega \mu \alpha \tau \alpha)$ de nuestra naturaleza es consecuencia lógica de la mezcla. Estando toda la vida humana manchada con el pecado, la potencia de limpieza (purificación, corrección) tenía que extenderse abrazándolo todo: comienzo, medio y fin (293). El que rechaza como vergonzosa la forma del nacimiento humano, podría decir que se introdujo en la vida desde el cielo. Pero no nos sería útil que la mezcla fuera con un ser celestial. Porque la parte enferma es la que debe recibir en particular la curación. Por lo demás, igualmente indigno hubiera sido que Dios se configurara a un cuerpo celeste, porque toda creatura está igualmente distante de Dios, el inaccesible. Y lo digno de Dios es hacer el bien al que lo necesita. Por eso acudió a donde estaba la enfermedad (294).

Los adversarios ridiculizan el modo de nacer. Pero, como se dijo antes, lo único vergonzoso por su naturaleza es lo malo y lo que le esté emparentado (295). Pero el orden $(\alpha \kappa \circ \lambda \circ v \theta \iota \alpha)$ de la naturaleza fue dispuesto por voluntad divina y, por tanto, está lejos de la acusación de maldad. Y la entrada que tiene el hombre a la vida es una sola. Todo el cuerpo humano es igualmente honroso, especialmente los órganos de la generación. Dios se mezcló, pues, con la vida humana por los mismos caminos por los que la naturaleza lucha contra la muerte (296)

En el número XXXII retorna este tipo de objeción. La naturaleza supereminente con su sobreabundancia de poder, ¿por qué debe llegar hasta la muerte y, sobre todo, al ultraje de la cruz? (297). Responde que el nacimiento hace necesaria la muerte, porque tenía que pasar por todas las particularidades ( $\_\llcorner\omega \mu \alpha \tau \alpha)$ de nuestra naturaleza (298). Pero con una mayor penetración en el misterio, se diría al revés: asumió el nacimiento por causa de la muerte (299), para llamarnos de nuevo de la muerte a la vida. Así, como tendiendo la mano al yacente, entró en contacto con el estado cadavérico ( $\vee \varepsilon \kappa \rho o \tau \eta \varsigma)$ y dio a la naturaleza el principio de la resurrección en su propio cuerpo (300). Antes había dicho nuestro autor, que Dios juntó de nuevo

(292) XXVI, 67, 9-20.

(293) No podía dejar algo $\alpha \theta \varepsilon \rho \alpha \tau \varepsilon v \tau o v$. El autor concibe, pues, el desarrollo sucesivo desde el nacimiento a la muerte, como las propiedades de nuestra naturaleza por asumir y como las partes de un todo por purificar. En ese sentido no tiene un concepto estático de naturaleza.

(294) Cf. XXVII. Según XXXIX, 101, 6-16, las creaturas no tienen mayor diferencia entre ellas, en cuanto todas pasaron por igual de la nada al ser. Así conforman una unidad.

(295) Dios, de lo único que está separado, es de la maldad.

(296) Cf. XXVIII.

(297) Recién reaparece un énfasis especial en lo indigno de la muerte.

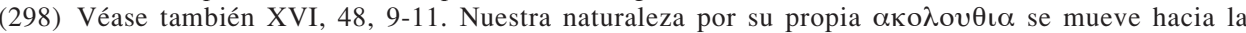
separación del cuerpo y del alma.

(299) Esta inversión muestra la centralidad que tiene, para nuestra salvación, la muerte y resurrección de Jesús. Anota Winling (ad 1. c.): Naissance et mort sont indissociablement liées, selon Grégoire. Il pratique deux approches pour le prouver: d'un côté, il invoque la loi naturelle en vertu de laquelle "la naissance rend la mort inévitable"; d'un autre côté, il part des données de l'Écriture et avance l'argument que la mort était nécessaire vu que Dieu voulait ramener l'homme de la mort à la vie à travers la mort et la résurrection du Christ: dans cette hypothèse, c'est la mort qui a rendu la naissance nécessaire.

(300) XXXII, 77, 7-78, 8. Véase $I b ., 78,18$ s. 
las partes separadas como (pegadas) con cola (la potencia divina (301)), reajustándolas en unidad irrompible. Y esto es la resurrección (302). Vuelve a unir de nuevo el alma asumida por Él a su propio cuerpo, mediante su potencia, mezclada desde la primera constitución con cada uno de los dos (303). Así llega a ser $\mu \varepsilon \theta o \rho ı s ~(304)$ de la muerte y de la vida: por un lado, habiendo detenido en sí mismo la disolución de la naturaleza por la muerte; por otro lado, llegando a ser principio de unión de lo dividido (305).

¿Y qué dice Gregorio sobre la cruz? Hay que considerar el sentido más elevado y divino: en la muerte ver lo humano, y en el modo de ella investigar lo más divino. Propio de la divinidad es coextenderse a través de todos los seres. Y el crucificado es el que 'conjunta' y ajusta a sí mismo el universo en un solo acuerdo y armonía. Cuando se piensa en la constitución de lo celeste y de lo subterráneo y de ambos extremos del universo, la divinidad es lo único que se nos presenta al pensamiento en todas partes y mantiene todo en el ser. Y era necesario que esto también nos llegara por la vista, por la cruz (306). Respecto a lo que sigue después de esto (307), los mismos incrédulos confiesan que no hay nada ajeno al concepto de Dios. No necesitan apoyo de razonamiento respecto a ser divinos (308).

Hasta aquí, en la segunda parte de la sección anterior y en esta, he resumido el desarrollo del argumento en pro de que el nacimiento, vida y muerte de Jesús, no es indigno de Dios. Fui siguiendo su espina dorsal a través de las diversas vueltas que tiene. Queda en clara evidencia que se trata de un Dios racional. Preferí este método de resumen para no perder demasiado la riqueza del escrito concreto. Ahora, en apretada síntesis, podría decir que la encarnación no es indigna de Dios, porque Este no se mezcla con ningún $\pi \alpha \theta$ os que implique la maldad (309), sino solo con los movimientos naturales de una creatura buena en sí (310). Si llega a la muerte (311), es, en último término, porque desde ahí va a pasar a la vida, consistiendo nuestra salvación en hacernos pasar a la vida (312) Así nos restaura en nuestra gracia

(301) Véase también, p. e. XXXV, 90, 2-5 (puede sumergirse en la muerte y volver de nuevo a la propia bienaventuranza); 90, 11-13.

(302) Para que fuera restaurada la gracia primera y de nuevo retornáramos a la vida eterna. Gregorio, al hablar, en este y otros pasajes, de la 'gracia primera', etc., presenta la salvación como una restauración, destacando así el valor de la creación

(303) Mezcla la substancia inteligible con la sensible. A mi parecer, en este pasaje insinúa que la divinidad en la muerte permaneció unida al cuerpo y al alma.

(304) Se trata de una frontera de incompatibles, que no son reunidos en armonía. Porque, en Cristo, la vida desplaza y vence a la muerte.

(305) Cf. XVI, 48, 9-49, 16. Véase XVI, 48, 4-9.

(306) Hace referencia a Ef 3, 18 y Flp 2, 10.

(307) Enumera: no permanecer en la muerte, existir pese a las llagas, aparecerse a sus discípulos cuando quería, estar en medio de ellos sin ser visto, fortificar a los discípulos con el soplo del Espíritu, prometer estar con ellos, elevarse al cielo y estar en todas partes, etc.

(308) XXXII, 78, 19-81, 24. Véase IX, 37, 4-7.

(309) Por lo demás, si Dios se mezcla con el hombre para mantenerlo en el ser, ¿por qué no para divinizarlo, como en la Encarnación, etc.?

(310) Con todo, el nacimiento proveniente de la $\rceil \delta o v \eta$ y la corrupción que sigue a la muerte, cosas que no se dieron en el caso de Cristo, el interlocutor los tendría por indignos.

(311) Si nace, tiene que morir. Pasa por todas las particularidades de nuestra naturaleza.

(312) Tiene que pasar por todo lo que abarca la vida humana, que toda estaba manchada con el pecado. Según XVII, 49, 24, nos salva por la $\pi \varepsilon \iota \rho \alpha_{\iota}$ de la muerte. 
primera. Por tanto, ha asumido íntegramente lo humano, su decurso (313). Este paso es una derrota del adversario que nos tenía preso. Este es engañado en justicia y, por lo demás, va a salir beneficiado. Así, Dios llega a tocar la muerte que desaparece como las tinieblas ante la luz (314). Vuelve a unir para siempre el alma con el cuerpo en la resurrección. Y si la muerte fue en la ignominia de la cruz es para darnos a conocer visualmente que Dios extendido en la cruz abarca el universo y lo armoniza en sí mismo. Por tanto, en esta economía no hay nada indigno de Dios (315). En nuestra redención Dios se muestra, a la vez, bueno, sabio, justo y poderoso. Y lo necesitábamos.

¿Cómo piensa Gregorio nuestra salvación? Si la muerte había sido introducida económicamente para que se escurriera la maldad, la resurrección de Cristo vuelve a unir, esta vez para siempre, el alma con su cuerpo. Y todos purificados terminarán entrando en el coro divino (316). En Cristo, la potencia de la divinidad, uniendo el alma al cuerpo, restauró la vida inmortal. Otra imagen de la salvación es por la desaparición automática ante la presencia de los contrarios (317) o por su contacto (318). Como la presencia de la luz disipa las tinieblas, así la vida respecto a la muerte. Todo esto es una manifestación del poder de Dios. En este sentido, es una salvación expresada en categorías descendentes. También la salvación se expresa en categorías de redención, en que Dios entrega al adversario, al que estábamos esclavizados o nos retenía encerrados, un rescate, contraproducente para él. Pero no hay ninguna alusión a categorías ascendentes, como las de sacrificio y expiación, o las de satisfacción y mérito, que tanta fortuna harán en Occidente (319). Esto concuerda con la cristología descendente, que hice notar en la conclusión respecto a las diferentes maneras de decir la Encarnación. Así, a través de la carne asumida por Él y deificada con Él, fue salvado todo cuanto era afín a la carne y de la misma especie (320). Dios se mezcló con lo humano para que lo humano fuera juntamente divinizado (321). Finalmente, el tema de la economía según el hombre y de su salvación,

(313) Véase lo dicho antes en las formas de decir la Encarnación.

(314) Además, la potencia divina, como fuego purificador, destruye todo lo contrario.

(315) Lo digno de Dios es hacer el bien al que lo necesita.

(316) La resurrección no aparece del todo bien armonizada con el tema de la restauración de los no purificados como natural, que insinúa en XXXV, 91, 5-15

(317) Cf. V, 20, 16-20; VIII, 35, 25-36, 5; XXIV, 62, 10-14; 63, 8s; XXVI, 66, 6-9. Véase XXVI, 66, 18-22. La aproximación de la potencia divina hace desaparecer, a modo de fuego, lo que es contrario, beneficiando a la naturaleza con la purificación, por penosa que sea la separación.

(318) Cf. p. e. XXIV, 63, 11-16; XXVII, 69, 7-12; XXXII, 78, 4-9.18s. El médico toca la parte enferma (cf. XVII, 50, 5s; véase XVI, 47, 1-3). Véase XXXVII, 93, 1-3.

(319) ¿Muestran las categorías descendentes, con más facilidad, un Dios razonable?

(320) Cf. XXXV, 86, 10-13. Véase XXV, 64, 6-10; XXXVII, 96, 20-22; 97, 21-98, 6. El cuerpo de Jesús fue inmortalizado por Dios (XXXVII, 93, 21-94, 12), elevado con la divinidad por la

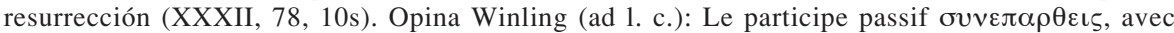
son double préfixe, représente une heureuse formulation, lourde de sens théologique (...). Il convient de distinguer des étapes dans le "mélange" entre la divinité et l'humanité du Christ. L'exaltation liée à la résurrection représente pour l'humanité du Christ une participation plus plénière à la gloire du Christ. Certes, le "mélange" est réalisé dès le début, mais il ne produit ses effets que progressivement. Respecto a XXXV, 86, 12, dirá después este autor: Le verbe composé

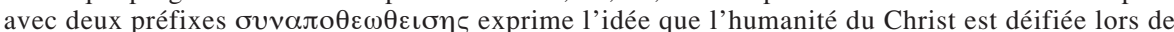
la résurrection en vertu de son étroite union avec le Logos et d'une participation plus plénière à ses privilèges.

(321) Cf. XXXVII, 97, 21-98, 1; XXV 64, 7-10. 
refuerza el conocimiento que ya teníamos de Dios en esta obra. Su bondad resplandece en su filantropía (322). La comparación que más aparece es la de médico (323). Cristo (Dios) es el que vivifica (324) y salva (325). Frente a la salvación del hombre caído, que aquí no entro a describir, aparecerá como $\alpha \rho \chi \eta \gamma o \varsigma$ de nuestra salvación

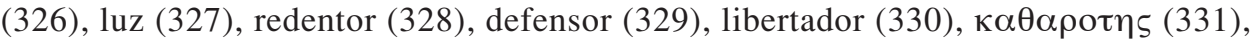
como el que levanta (332), reconduce (333) nuestra naturaleza hacia el bien, etc.

\section{RESURRECCIÓN Y APLICACIÓN DE LA SALVACIÓN}

Pero con lo dicho hasta ahora no basta para la economía de un Dios razonable. Porque solo en el guía de nuestra salvación se ha cumplido completamente la economía según la muerte (334). Para ser razonable, la salvación tiene que llegar a cada uno de nosotros. Y, como vimos antes, en Gregorio ella llegará hasta la apocatástasis (incluido el adversario). Ya se presentaron, al tratar de la bondad de Dios y del mal del hombre, algunas objeciones al respecto: por qué tan tarde, por qué todavía sigue el hombre complicado con el mal, por qué no ha llegado a todos la gracia de la fe. Es básica la repercusión universal de la resurrección. Las cuatro prolongaciones de la cruz, ya lo habían graficado. Gregorio, además, afirma algunas veces que la

(322) Cf., respecto a $\phi \iota \lambda \alpha v \theta \rho \omega \pi \iota \alpha, X V, 43,15 s ;$ XX, 54, 2-11; XXIV, 61, 3s; XXVI, 64, $26-65,4$.

(323) P. e.: XV, 43, 18s; XVI, 46, 22-47, 3; XVII, 50, 2-8; XX, 54, 11-15; XXVI, 67, 2-7.19-21; XXVII, 69, 7-12; 70, 17s; XXIX, 72, 21-XXX, 74, 7. Si solo nos fijamos en algunos vocablos, Ł $\alpha \rho \varepsilon v \omega$ y los substantivos y adjetivos correspondientes aparecen 9 veces y $\theta \varepsilon \rho \alpha \pi \varepsilon v \omega$ y sus substantivos, 23, en relación a nuestro tema. Véase XXXVII, 93, 8-17; 94, 1-4. Según J. R. Bouchet (La vision de l'économie du salut selon S. Grégoire de Nysse, RSPhTh 52 (1968) 613644, p. 643), nul autre nom du Christ pendant l'économie, pas même celui de lumière, n'a dans 1'oeuvre de Grégoire de Nysse le relief de celui de médecin.

(324) Cf. XV, 43, 20; XXIV, 63, 13s; XXVI, 66, 6-9; XXXV, 86, 11; XXXVII, 93, 18s; 94, 8; 95, 26-96, 1. Véase: XVI, 48, 17; XVII, 49, 21; XXIV, 62, 10-14; 63, 9.16; XXV, 64, 10-12; XXXII, 78, 2s;

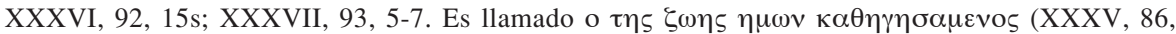
16s; 88, 2s; XXXVII, 93, 2s). Es el $\mu \varepsilon \theta 0 \rho ı$ de la vida y de la muerte (XVI, 49, 13-16). Recordemos que es propio de Dios dar la vida y que el Logos ha sido llamado $\alpha v \tau$ ¿ $\zeta \omega \eta(\mathrm{I}, 9,25)$.

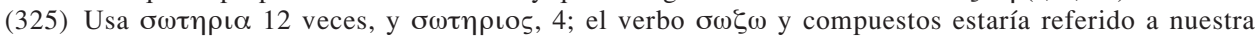
salvación 11 veces.

(326) XXXV, 86, 18; 87, 14s. Véase XXXIX, 100, 17-19.

(327) XV, 43, 22s; XXIV, 62, 11-14; 63, 8s; XXVI, 66, 6-9. Cf. V, 17, 4 ( $\phi \omega \varsigma$ у $\delta о \xi \alpha$ dice Gregorio del Dios Logos).

(328) XV, 43, 23s; XXIII, 60, 20s. Cristo es el $\lambda v \tau \rho o v$ (XXII, 58, 2-4; XXIII, 60, 3-5). Véase XXII, $57,22 \mathrm{~s}(\varepsilon \xi \omega v \varepsilon \iota \sigma \theta \alpha \iota)$.

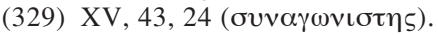

(330) XV, 43, 25 ( $\varepsilon \lambda \varepsilon v \theta \varepsilon \rho \omega \tau \eta \varsigma)$. Véase XV, 44, 7-9 (lo arrancaría del poder del enemigo y devolvería al estado inicial); XXII, 57, 24-58, 4; XXV, 64, 9s (1legado a estar fuera de la tiranía del adversario); XXVI, 67, 18s.

(331) XXIV, 63, 12s. Cf. XVII, 49, 20s; XXIV, 63, 14s; XXVI, 66, 9s; 67, 20s; XXVII, 68, 11; XXXVI, 92, 18. La divinidad es el verdaderamente puro, en cuya pureza participa el purificado

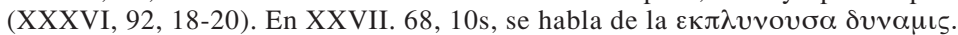

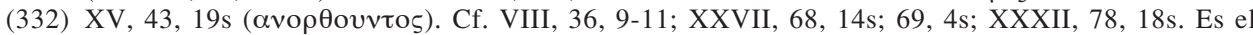
que vuelve a llamar, reanima ( $\alpha v \alpha \kappa \alpha \lambda \varepsilon \iota v, \alpha v \alpha \kappa \lambda \eta \sigma \iota)$ : VIII, 34, 12s.16s; 36, 8-10.13s; XXI, $57,7 \mathrm{~s} ;$ XXII, 58, 1s; XXXII, 78, 2s.

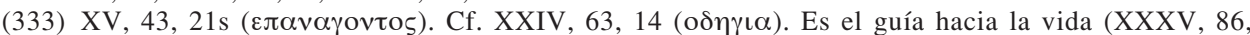
16s.24; 87, 3-14; 88, 2s.18s; 89, 2; XXXVII, 93, 2s). Necesitábamos de lo que reúne

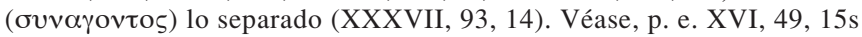

(334) Cf. XXXV, 88, 18-21. 
resurrección de Jesús es el comienzo de la nuestra, desde ahí se extiende hacia nosotros (335). ¿Cómo es esto posible? Así como el principio de la muerte se traspasó de uno solo a toda la humanidad, así también el principio de la resurrección, gracias a uno solo, se extiende, en potencia $\left(\tau \eta_{\iota} \delta v v \alpha \mu \varepsilon \iota\right)$, a toda la naturaleza humana (336). Porque la naturaleza humana conforma una sola masa, de la que es Cristo. Con su propio cuerpo dio a la naturaleza el principio $(\alpha \rho \chi \eta v)$ de la resurrección, resucitando con su poder conjuntamente al hombre entero. Puesto que el hombre $\theta \varepsilon o \delta o \chi 0 \varsigma$ era de nuestra pasta. Como si la naturaleza entera fuera la de un solo ser vivo, la resurrección de un miembro se extiende al todo por la contigüidad y unión de la naturaleza (337). Pero esto no quiere decir que sea automática o 'física', en el sentido que no se deba ir aplicando a cada uno. El caso extremo es el de los que no se purifican en esta tierra y serán purificados después. Entonces retornarán sanos y salvos a Dios, a la bienaventuranza, sin pasión (338).

La salvación, pues, se hace efectiva, para nosotros, mediante la purificación del agua (339), en el bautismo (340), regeneración en que se nace para la vida inmortal, incorruptible (341). Este nacimiento se realiza por la potencia divina que transforma la naturaleza corruptible en incorruptible (342). ¿Cómo sabemos que está presente y activa? Porque el que es Dios lo ha prometido: estar en medio de los creyentes, permanecer en todos, estar con cada uno. La invocación contribuye (343). ¿Cómo opera esto? La salvación nos viene por el contacto con Cristo (344), por el seguimiento e imitación de nuestro guía (345), que nos conduce a través del laberinto de esta vida, fuera de la prisión de la muerte (346). Imitamos sus tres días de muerto depositado bajo tierra y su resurrección, sumergiéndonos tres veces bajo el agua y surgiendo de nuevo (347). Nos es, pues, necesario preludiar en el agua la

(335) Su resurgimiento de la muerte se convierte, para la raza mortal, en comienzo del resurgimiento a la vida inmortal (XXV, 64, 10-12)

(336) Cf. XVI, 48, 21-49, 16. Es el principio de la reunión de lo separado. Este principio va derecho, en

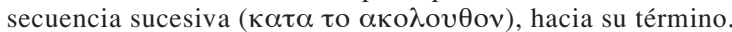

(337) XXXII, 78, 4-17. Afirma Barbel, op. cit., Komm. 133, p. 132: Selbstverständlich tritt Christus dadurch, dass er einen bestimmten, individuell geprägten Menschen angenommen hat, in Berührung mit der gesamten menschlichen Natur.

(338) Cf. XXXV, 88, 16-18; 90, 5; 91, 17-19; 92, 1-3; XL, 106, 14s. Véase VIII, 29, 16s.

(339) XXXV, 91, 16-20; 92, 3-6; XXXVI, 92, 18-21. Como ya vimos, nadie puede llegar a ser del coro divino, participar de Dios que es la misma pureza, sin estar purificado (XXXVI, 92, 9-11.18-20).

(340) Puede verse, Winling, op. cit., p. 314 n. 1.

(341) XXXII, 82, 1-XXXIII, 82, 14.

(342) Cf. XXXIII, 84, 3-5. Así como transforma el semen en hombre (XXXIII, 82, 23-84, 5; cf. XXXIV, $85,5-16)$. El misterio de la regeneración se realiza mediante la oración a Dios, la invocación de la gracia celeste, el agua y la fe (XXXIII, 82, 15-17). Cf. XXXV, 91, 20-22; XXXVI, 92, 21.

(343) Cf. XXXIV. Dios ha depositado en esa operación la potencia de parte suya. La gracia se haría presente en los regenerados. Véase XXXVI, 92, 14-16 (Dios presente en todo, obra lo propio, asistiendo a los que invocan su poder vivificante).

(344) Cf. XXXVII, 93, 1-3. El alma por la fe se une ( $\varepsilon \phi \alpha \pi \tau \varepsilon \sigma \theta \alpha \iota, \alpha \nu \alpha \kappa \rho \alpha \theta \varepsilon \iota \sigma \alpha, \varepsilon v \omega \sigma \iota \varsigma)$ al guía hacia la vida, teniendo ahí los comienzos de la salvación, la comunión con la vida (cf. XXXVII, 93, 2-6).

(345) Porque el modo de nuestra salvación se hizo eficaz no tanto a partir de la guía de la doctrina, cuanto por los actos de Cristo (XXXV, 86, 8-10).

(346) Cf. XXXV, 86, 13-87, 14.

(347) Cf. XXXV, 87, 15-88, 12; 89, 20-23. Lo imitamos en cuanto podemos (el resto está reservado para el tiempo futuro). No totalmente, porque no morimos. Si muriéramos, la maldad desaparecería totalmente. Ahora nos libramos, en cierto modo, de la afinidad con el mal por el arrepentimiento y la imitación de la muerte (XXXV, 89, 1-20). 
gracia de la resurrección. El gran y mejor bien de nuestra resurrección (348) tiene aquí sus principios y causas (349).

Pero la fe (350), en el momento del bautismo (351), debe ser en la Trinidad increada, para que lo realizado ahí tenga poder (352), para que nazcamos a la vida inmutable. Nosotros elegimos libremente qué naturaleza queremos tener por padre. Si pensamos que el Hijo y el Espíritu son creados, regresamos, en cierto sentido, a lo que nos era connatural, a la vida mudable, y el nacimiento ha sido de abajo y no de arriba, espiritual (353)

Obviamente esta imitación de la muerte y resurrección de Cristo va acompañada del arrepentimiento (354). El nacimiento 'salutífero' se recibe para renovación y transformación de nuestra naturaleza. Así, agrega Gregorio, el nacido de Dios tiene que mostrar en sí los rasgos del Dios que lo engendró, tiene que mostrar en sus elecciones el cambio de vida (355). De lo contrario, se atrevería a decir que el agua fue solo agua, no manifestándose el don del Espíritu. No ha nacido en realidad de arriba (356). Esto lleva a nuestro autor a hablar, como ya vimos, de premios y castigos futuros, con lo que concluye su libro.

Pero no basta con el bautismo y la fe que se refiere a la salvación del alma. Porque el hombre es también cuerpo. ¿Cómo, pues, puede nuestro cuerpo entrar en contacto con el salvador para que se le aplique la salvación: la vida, la inmortalidad? (357). La única forma que tiene el cuerpo de entrar en contacto, de recibir el antídoto, es por el alimento y la bebida, que se transforma en sus entrañas en su cuerpo y sangre. En ese sentido el cuerpo humano es pan, porque se alimenta de él (358). Y el

(348) No se refiere a la simple restauración del compuesto humano que acontecerá necesariamente a todos según la economía, sino a la apocatástasis del estado feliz y divino de los purificados por el bautismo. Porque los no purificados por el agua, serán purificados por el fuego (cf. XXXV, 91, 3$92,8)$. Esto ya lo vimos a propósito de la bondad de Dios y el mal del hombre. El purificado participará de la verdadera pureza, que es Dios (XXXVI, 92, 18-20).

(349) Cf. XXXV, 90, 14-91, 5. Compara con la necesidad del semen para que después exista un hombre. El principio, comparado con el fin, parece de ninguna importancia. Lo fácil que nos es bautizarnos, nos enseña que para nosotros va a ser igualmente fácil resucitar, como le fue fácil a Cristo, potencia divina (XXXV, 90, 9-16; cf. Ib., 90, 1-9). Dirá después que el bautismo es el fácil principio y fundamento (fe y agua) de grandes bienes: la familiaridad con la divinidad (XXXVI, 92, 11-25).

(350) La fe, con la que complementa su catequesis, se refiere a la fe trinitaria.

(351) Cf. XXXIX, 100, 21-101, 1.

(352) Lo realizado tiene su fuerza según la disposición del corazón del que se acerca a la economía (XXXIX, 99, 22-100, 2).

(353) Cf. XXXVIII, 98, 18-XXXIX, 102, 3. Necesariamente lo engendrado es de la misma raza que los engendrantes. Debemos hacer a la naturaleza inmutable fuente $(\alpha \rho \chi \eta \gamma o v)$ de nuestra propia vida.

(354) En XXXV, 91 20-22, junto con el agua mistérica y la invocación de la potencia divina, se habla de la enmienda del arrepentimiento. Cf. Ib., 89. 9s.12s. En VIII, 32, 7-34, 2, para las manchas del alma, se propone el remedio de la virtud. De lo contrario, los dolores del juicio.

(355) Un alma lavada de las manchas de las pasiones. Porque algo tiene que cambiar para que la gracia de la regeneración sea cumplida.

(356) Cf. XL, 102, 5-105, 9.

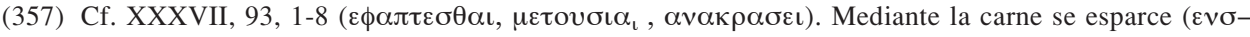

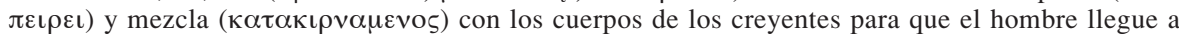

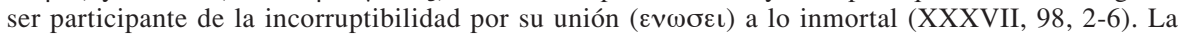
única forma que tiene nuestro cuerpo de llegar a la inmortalidad es participar en la incorrupción por la comunión con lo inmortal (XXXVII, 94, 10-12). Véase XXXVII, 95, 26-96, 1.

(358) Cf. XXXVII, 93, 8-17; 94, 5-7; 95, 15-23; 96, 3-6.13-15; 97, 12-20. La bebida es el agua, muchas veces temperada con vino para ayudar al calor interno. Nuestro cuerpo no tiene la vida en una subsistencia propia, sino por lo que ingiere, por la fuerza del alimento (XXXVII, 94, 20-95, 11). Es la forma posible, para el cuerpo, de recibir la potencia vivificadora (véase XXXVII, 94, 7s). 
único cuerpo del Logos es también pan en cierto sentido (se alimentó de pan y vino) y se mezcla con los cuerpos de los que han creído, repartido siempre íntegramente en muchos sitios y conservándose íntegro en sí mismo (359). Y el cuerpo (y sangre) de Cristo, más fuerte que la muerte e iniciador de nuestra vida (360), inmortalizado por Dios, introducido en nosotros, transforma por entero nuestro cuerpo en su propia naturaleza (361). Entonces el Verbo de Dios transformó el cuerpo de Jesús (que era pan en cierto sentido) en dignidad y potencia divinas, lo santificó; ahora santifica y convierte el pan inmediatamente en su cuerpo sin pasar por comerlo Él mismo (362). Así dijo: esto es mi cuerpo (363). Por el poder de la $\varepsilon v \lambda o \gamma \iota \alpha$ transforma ( $\mu \varepsilon \tau \alpha \sigma \tau o \iota \chi \varepsilon \iota \omega \sigma \alpha \varsigma)$ la naturaleza de lo que aparece en su cuerpo (364).

En resumen y en palabras mías, si en la muerte nos liberamos del mal, lo que permitirá nuestra replasmación por Dios, es en la resurrección donde se vuelve a juntar para siempre el alma con el cuerpo, e ingresamos en la vida incorruptible, inmortal. Pero solo cuando se está del todo purificado se retorna sano y salvo a Dios, para una bienaventuranza (sin pasiones) eterna. Es la culminación de la economía salvadora de Dios, donde resplandece su bondad y su victoria sobre el mal. Ya

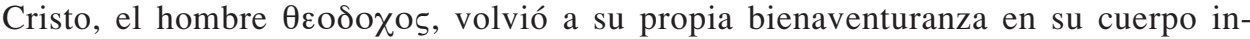
mortalizado (365). Y la resurrección de Cristo se expande a toda la naturaleza humana divinizándonos a todos, junto con Él. Y al final, brotará un himno de acción de gracias de parte de toda la creación. Pero, ¿cómo sucede esto en nosotros? Para el alma por el bautismo, imitación de la pascua de Cristo que culminará en nuestra muerte y resurrección, y para el cuerpo por la comida eucarística. Por bautismo purificador entiende Gregorio renacer realmente como hijos de Dios, de la Trinidad. Así, Dios sigue mostrándonos su presencia salvadora. Y su economía es razonable.

\section{PALABRAS CONCLUSIVAS}

He pretendido hacer una presentación resumida de los aspectos principales de Dios en esta obra. No pretendo repetir ahora paso a paso las conclusiones de cada parte (366). Tanto Dios mismo como su economía se han mostrado razonables. En este discurso catequético apologético comenzamos por el único Dios que es Trinidad (367) y terminamos con esta en los misterios del bautismo y de la Eucaristía. Con todo, fuera de lo anterior y del Logos en la creación, los términos Logos y Espíritu

(359) Cf. XXXVII, 94, 13-16; 95, 26-96, 2; 96, 6-20; 98, 1-4. Véase XXXVII, 97, 20s.

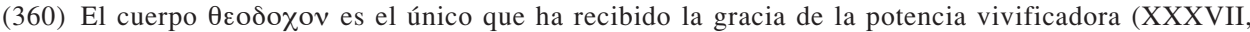
94, 7-10). Vivifica toda la naturaleza de los hombres en los que hay fe (XXXVII, 95, 26-96, 1).

(361) Cf. XXXVII, 93, 18-94, 4. Como un poco de levadura asimila toda la masa a ella. Véase XXXVII, 93, 13-17.

(362) Cf. XXXVII, 96, 20-97, 11. Santificado el pan por el Logos de Dios y la plegaria.

(363) XXXVII, 97, 11s.

(364) XXXVII, 98, 6s.

(365) Cf. XXXV, 90, 4s

(366) Por eso, contra la costumbre, pongo algunas notas en la conclusión, remitiendo a algunas citas entre aquellas que quizás no sería tan fácil para el lector encontrar en el cuerpo de este trabajo.

(367) Gregorio se mueve entre el polo de la distinción y el de la unidad. Está última parece estar más fundada en la naturaleza divina que en el Padre. 
(368), salvo este último una vez, nunca son usados. El uso de П $\alpha \tau \eta \rho$, referido al Padre del Logos o Hijo, es aún más escaso en toda la obra. La terminología, pues, poco trinitaria y, dentro de esta, que el Logos desplace fuertemente al término 'Hijo' (y, por tanto, al 'Padre'), confirma la presentación de un Dios racional para judíos y griegos (369).

Comienza en la existencia de Dios y termina en los premios y castigos escatológicos. De tal modo está centrado en el misterio de la Encarnación salvadora, que, respecto a la historia del A. T., solo alude a cosas como el paso del mar rojo por Moisés, comparándolo con el andar de Jesús sobre las aguas (370). Gregorio, después de presentar la Trinidad, habla de la creación buena, del acuciante problema del mal del hombre, introducido por la libertad de este, engañado por el adversario. Dios responde con la economía según el hombre, Encarnación que culmina en la muerte (en cruz), y resurrección, la cual es comienzo de nuestra restauración según la gracia primera, y cuya aplicación a nosotros sucede en el bautismo y Eucaristía. Estos últimos, con el añadido de la fe trinitaria y el respectivo cambio de vida en el verdadero bautismo, completan la enseñanza catequética. Todo terminará en la resurrección para bienaventuranza, en la apocatástasis (371), triunfo final de la bondad de Dios. Dos veces me detengo a enumerar especialmente atributos de Dios: la primera en el marco titulado 'Dios y su creatura', la segunda al terminar la obra redentora de Cristo, a propósito de ella. Los capítulos del presente trabajo siguen, a grandes pasos, el desplazamiento de la obra de Gregorio, pero con un esfuerzo de concentrar las citas temáticamente.

El centro de la obra está dedicado, pues, a la Encarnación que implica la muerte, a nuestra redención, lo que muestra juntamente la bondad, sabiduría, potencia y justicia de Dios. El tema de la justicia está muy concentrado en la relación con el adversario en la redención. Defiende que esta economía según el hombre no es indigna de Dios. Me detuve un poco en el modo como expresa la Encarnación. También me interesó la forma en que el Salvador desplaza la muerte y las tinieblas. Muestra una clara cristología descendente, pero expresada en términos antioquenos, que respetan la naturaleza humana. Así llega a hablar del cuerpo y hombre

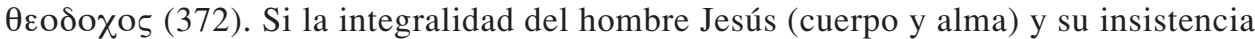
en la naturaleza humana (373) (humanidad) de Dios, es antioquena, su cristología descendente muestra claramente que el sujeto es Dios. Los vocablos atinentes a la 'mezcla' comprueban la unidad. Dios se mezcló con lo nuestro para que lo nuestro llegara a ser divino. Somos co-divinizados en el hombre Jesús (374). La transforma-

(368) El Espíritu acompaña siempre al Logos, como el hálito a nuestra palabra. Porque respiramos el aire $(\pi v \varepsilon v \mu \alpha)$ y este puede convertirse en voz que manifiesta en sí misma el poder de la palabra.

(369) El hablar, a propósito de la Encarnación, normalmente de Dios y no del Logos, manifiesta también la fuerte asimilación del consubstancial de Nicea.

(370) XXIII, 59, 4-9. Cf. también XVIII, 52, 9-11; XXIII, 59, 11; XXIX, 73, 13-15.

(371) Pero previamente, los no purificados sufrirán penas indecibles.

(372) XXXII, 78, 10; XXXVII, 94, 9; 96, 16; 97, 20s.

(373) Con todo, en XIII, 42, 22-43, 2, llega a exclamar que no está del todo dentro de la naturaleza por su nacimiento virginal. Véase XIII, 41, 10-12; 42, 4-11.

(374) Cf. p. e. XXXV, 86, 11-13; XXXVII, 97, 21-98, 1. Afirma Kees sobre nuestro autor (op. cit., 288): Weil Christi Menschnatur vergöttlicht worden ist, wird alles Leibliche verwandelt werden. Von der Vergöttlichung der Natur aller Menschen spricht Gregor von Nyssa im Gegensatz zu Gregor von Nazianz nicht. Er spricht von der Verwandlung, von der Angleichung an Gott. Die 
ción del hombre por la resurrección no implica que este deje de ser tal, sino que se trata de participación en los bienes divinos (375). Por el problema de la muerte y resurrección destaca claramente el alma de Cristo. Pero el alma de Cristo, fuera de volver a ser unida con el cuerpo, no juega ningún papel especial en esta soteriología descendente. Insinúa que la divinidad permanecería unida al cuerpo y al alma en la

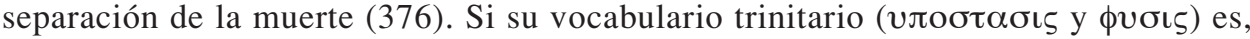
en varios textos, correcto, el cristológico va a quedar sobrepasado en el siglo siguiente, p. e. las expresiones de mezcla, pero su fondo es totalmente ortodoxo.

Así como la cristología es predominantemente descendente, igualmente las categorías de redención (377): no aparecen ni sacrificio ni expiación, tan presentes en el N. T. Me atrevo a sintetizar como lo más central lo siguiente: toma nuestra muerte para darnos su vida (378). Por eso, más profundamente que morir porque había nacido, nació para morir (379). Para llegar, o al llegar a la muerte, la divinidad, oculta en el envoltorio de la carne, engaña al adversario. Así, Jesús es escogido por este como rescate (380). Dios había introducido la muerte para que, en la separación del alma respecto al cuerpo, se escurriera el mal, y así el cuerpo pudiera ser replasmado. En la resurrección, Dios, unido al cuerpo y alma de Jesús, los vuelve a reunir para siempre (381). Así nos restaura, porque la naturaleza humana forma una unidad (como un solo viviente) (382), y de la misma manera como la muerte, sucedida en uno, se extendió a toda la naturaleza humana, así la resurrección restauradora (383).

Pero esta concepción descendente puede prestarse a un cierto sabor mecánico, como en el desplazamiento de las tinieblas por la luz. No es, sin embargo, la redención física (384) en que quedara redimida automáticamente toda la naturaleza humana, pues tiene que ser aplicada a cada uno, e insiste repetidamente en que la fe y el bautismo son libres, y el bautismo verdadero implica un cambio de vida, además de una fe ortodoxa. Y si el bautismo no va acompañado de un cambio de vida, se atreve a decir que el agua es simplemente agua (385). Igualmente anima con los grandes

Menschen können durch den Glauben und die Taufe an der Vergöttlichung des Menschen in Christus teilhaben. Was bei Christus aufgrund der engen, naturhaften Vereinigung von Gott und Mensch vollkommen und endgültig geschehen ist, steht allen anderen Menschen qua Anteilhabe als unendlicher Prozess bevor: die Verähnlichung mit Gott.

(375) Esto que es claro en el caso del cristiano, ¿podría aplicarse a lo que se dice del Jesús resucitado en otras obras? Cf. J. R. Bouchet, Le vocabulaire de l'union et du rapport des natures chez Saint Grégoire de Nysse, RTh 68(1968)533-582, pp. 564-577. Respecto a $\mu \varepsilon \tau \alpha \pi$ oเعı en esta obra, véase Srawley, op. cit., p. 143, lín. 5.

(376) XVI, 48, 24-49, 1.

(377) Cf. S. Zañartu, Documento de la Comisión Teológica Internacional sobre la redención. Presentación con algunos comentarios, Teología y Vida 42 (2001) 20-49.

(378) Cf. p. e. XXXII, 77, 24-78, 9.

(379) XXXII, 77, 21-24.

(380) Cf. p. e. XXII, 60, 1-17.

(381) En la resurrección alcanza su objetivo (cf. XV, 44, 13s).

(382) XXXII, 78, 9-17.

(383) Cf. XVI, 48, 21-49, 16

(384) Véase al respecto, A. Harnack, Lehrbuch der Dogmengeschichte, II, 5a ed., Tübingen 1931, pp. 166-168.

(385) XL, 103, 8s. Y el cuerpo de Cristo, repartido en la Eucaristía, vivifica toda la naturaleza de los hombres en los que hay fe (XXXVII, 95, 26-96, 2). 
bienes que nos esperan y amenaza con la terrible y larga purificación de la otra vida. Nadie que no esté purificado entrará en el coro divino (386). Por estas mismas razones, la aplicación de la redención por medio de los sacramentos no sería meramente mecánica.

La resurrección es obviamente digna de Dios. Repercute en toda la naturaleza humana. En los números finales se trata de la aplicación de la muerte y resurrección de Cristo a todo cristiano. Resucitó con su poder conjuntamente al hombre entero (387). El cuerpo de Jesús es inmortalizado en la resurrección. Y esto se extiende a nosotros: el cuerpo de Jesús, por la comunión eucarística, asimila nuestros cuerpos al suyo para que participemos de la incorruptibilidad (388). Respecto a la purificación del alma, renacemos como hijos de la Trinidad en la imitación del bautismo con su triple inmersión (389).

Todo esto está subtendido por el mal, que surge en la naturaleza mudable del hombre, en su libertad, y su desvanecimiento automático ante la luz, etc., y por el contacto con el Salvador. Necesitábamos un salvador. En la apocatástasis final (aun del adversario) todo quedará purificado y retornará a Dios en una gran acción de gracias de toda la creación (390). Lo que más se destacaría sería la bondad de Dios. El hombre es creado y salvado por esa bondad. Aclarando: el verdadero mal, que es no ser (ausencia de virtud), solo existe en la libertad, el mejor de los dones, la cual, como creada (pasada del no ser al ser), siempre está en movimiento. Pero no se hubiera debilitado la bendición de la creación que tenía el hombre, si no es por el engaño de quien pecó primero, el inventor de la maldad. El pecado del adversario se debió a la envidia de que el hombre, su subordinado, fuera imagen de Dios. Entonces, solo el $\pi \alpha \theta 0 \varsigma$, en sentido propio, es maldad. El simple movimiento, como por el que pasó Dios al nacer y morir, no lo es (391). Jesús nació de una virgen y no sufrió la corrupción. La muerte (purificadora) propiamente no es un mal, sino un exceso del beneficio divino (392). La verdadera resurrección es a la vida sin $\pi \alpha \theta$ os, bienaventurada (393).

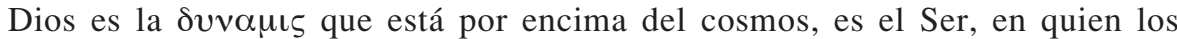
seres subsisten. Es la misma vida; nosotros solo participamos de ella (394). Es la naturaleza inmutable que se contrapone a la creación mudable, que pasó del no ser al ser. Dios crea por sobreabundancia de amor (395). El cosmos es bueno (396). El hombre fue creado con algo divino para que tienda hacia Dios (397). El plan de

(386) XXXVI, 92, 8-11.

(387) XXXII, 78, 6-9.

(388) Cf. XXXVII, 93, 20-94, 1; 98, 1-6.

(389) Cf. p. e. XXXV, 88, 5-12; 89, 18-23; XXXIX, 99, 13-22.

(390) Cf. XXVI, 66, 4-6; 66, 18-67, 2; 67, 9-13.18-20; XXXV, 91, 10-12; 92, 1-3, etc.

(391) Cf. XVI, 46, 3-14.

(392) VIII, 29, 4-6. Es propio de los animales discernir lo bueno y lo malo por las penas y los placeres (VIII, 34, 25-35, 1).

(393) Cf. VIII, 29, 16s; XXXV, 88, 16-18; 91, 17-19.

(394) I, 9, 22-26.

(395) $\mathrm{V}, 17,1-3$

(396) A pesar de las oposiciones, como sensible e inteligible, el autor destaca cierta armonía de lo sensible y cierta mezcla de sensible e inteligible para que todo pueda participar por igual del bien (cf. VI, 21, 7-22, 18). Véase XXVII, 69, 18-70, 16; XXXIX, 101, 6-16.

(397) Cf. V, 17, 13-16; 17, 20-18, 9; 19, 15-19. 
Dios, por exceso de bondad, es la participación del hombre, síntesis de lo sensible e inteligible, en los bienes divinos. El hombre es imagen de Dios (398). La libertad del hombre, que Dios respeta profundamente, es el mejor de los bienes, por los que se asemejaba a Dios (399). Pero esa libertad creatural desembocará en el mal. Pero lo propio de Dios es salvar a los que lo necesitan (400). Y Dios manifiesta mayor poder en el abajamiento de la Encarnación que en las maravillas de la creación y de los milagros (401). A través de la obra Gregorio manifiesta una gran valoración de la gracia primera de la creación (402), que es restaurada. Dada la caída del hombre, Dios introduce temporalmente la muerte para purificar (403). Y con la muerte y resurrección de Cristo restaura.

Destaco otras pinceladas. La presentación del misterio, lo lleva a un tratado donde la cristología se entrelaza con la antropología, reforzándose mutuamente (404). Defendiendo la Encarnación, defiende la bondad del mundo, del cuerpo humano. La prueba de la divinidad de Jesús es resueltamente el milagro (405). Sabroso es lo del engañador engañado, eligiendo libremente el enemigo como rescate a Jesús dentro de una justicia contractual. Cristo llega a ser $\mu \varepsilon \theta$ opıos (límite, confín), que detiene en sí la disolución de la muerte y es principio de la vida resucitada (406). Utiliza mucho la imagen médica (407). La cruz representa la salvación cósmica; en ella está extendido el cohesionador y armonizador del universo (408). Lo tardío de la redención fue para que culminara el mal y así comenzar a curarlo (409). El mal, mortalmente golpeado en su cabeza, sigue dando coletazos (410). La libertad del hombre, respetada por Dios, es la que no acepta la gracia de la fe ofrecida a todos por igual (411). La sabiduría del plan de Dios se muestra también en los hechos históricos: desplazamiento del culto pagano y judío por el cristiano (412). El poder de la bendición en la Eucaristía transforma la naturaleza de lo que aparece (413). Establece un paralelismo entre el cuerpo de Jesucristo (en cierto sentido pan) transformado por el Logos en dignidad divina y el pan convertido inmediatamente, por el Logos, en cuerpo de Cristo que transforma nuestros cuerpos en su naturaleza, en la comunión eucarística. El progreso en el bien no tiene límite (414).

(398) La imagen está en el interior. No es tocada por la mortalidad (VIII, 30, 16-20).

(399) V, 19, 19-20, 5. Cf. XXX, 75, 13-17.

(400) Cf. p. e. XII, 40, 21s; XXVII, 70, 16s; XXXVI, 92, 16s.

(401) Cf. XXIV, 61, 4-62, 3.

(402) VIII, 32, 21-23; 34, 16s; 36, 8s; XVI, 48, 16-18.

(403) Cf. p. e. VIII, 29, 18-31, 21.

(404) El hombre es concebido como unión de cuerpo y alma, de sensible e inteligible. El hombre es central en la armonía del mundo para que todo participe de Dios; Cristo (Dios) en la cruz armoniza el mundo. El cuerpo, cuya bondad se defiende, va a recibir un énfasis especial del cuerpo de Cristo que comulgamos en la Eucaristía.

(405) En Cristo hay que ver lo humano y considerar lo divino (XXXII, 79, 3-12).

(406) XVI, 49, 13-16.

(407) El médico que cura el $\pi \alpha \theta$ os, permanece fuera de él (XVI, 46, 22-47, 3).

(408) Cf. XXXII, 79, 12-80, 18

(409) Cf. XXIX.

(410) XXX, 74, 5-14

(411) Cf. XXX, 74, 14-76, 5. Esta afirmación, como la sobre la apocatástasis de todo, es parte de la forma cómo Gregorio muestra un Dios razonable.

(412) Cf. XVIII.

(413) XXXVII, 98, 6s.

(414) XXI, 55, 23-56, 1 
Obviamente que los contrincantes han ido variando. Si en el problema del mal parecen ser principalmente los maniqueos, en el añadido final, los herejes trinitarios y los malos cristianos. En el resto suelen caracterizarse preferentemente como el helenismo politeísta y el judaísmo. Ambos no aceptan la Trinidad, pero sobre todo la economía según el hombre (415). Recordemos sí que la catequesis se dirige más inmediatamente a los que están al frente del misterio de la piedad en el proceso de agregarse nuevos convertidos (416) del helenismo y judaísmo. En ese sentido es una catequesis para los cristianos en confrontación con los otros, y con los herejes. Es una obra muy bien construida e inculturada, que revela la madurez de su autor. Constituye una joya de la Iglesia antigua. Su género literario sería el de una gran catequesis, apologética y dialogada. Busca la persuasión y, por eso, se esfuerza en presentar un Dios razonable en el misterio de la piedad. Su teología negativa (417),

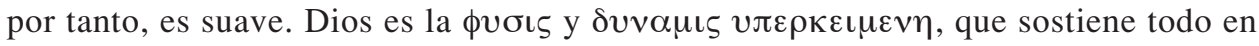
el ser. No todo lo que dice está perfectamente afinado. Por ejemplo, ¿la corrupción corporal es un mal propiamente?, ¿cuál es la relación entre la simple reconstitución del compuesto en el caso de los no purificados, y la resurrección? (418).

\section{RESUMEN}

El articulista, después de introducirnos en este tipo de escrito y sus destinatarios, nos presenta todo el material sobre Dios que en él aparece, remitiéndonos a innumerables citas. Gregorio usa relativamente poco el vocabulario trinitario, centrándose en Dios. Presenta los

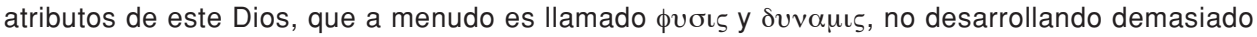
una teología negativa. A Dios se lo conoce por sus obras; la divinidad de Cristo por los milagros. Dios crea y salva por bondad. El mundo es bueno y el hombre fue creado en todo bien para que participara en los bienes divinos. El verdadero mal es ausencia de virtud y surge en la libertad. El hombre pasa a ser mortal para que el cuerpo sea purificado del mal por la muerte. No es indigno de Dios el nacimiento y la muerte. Cristo, al tocar la muerte la hace desaparecer y vuelve a unir para siempre el cuerpo y el alma. Dios nos ha liberado por bondad y con sabiduría, poder y justicia (respecto al adversario). La redención se nos aplica por la imitación del bautismo y la comida eucarística que nos transforma hacia la incorruptibilidad. El alma no purificada por la virtud, será purificada por el fuego del juicio para retornar a la gracia del principio, apocatástasis. Su cristología y redención es sobre todo descendente. En todo se muestra un Dios razonable.

\section{ABSTRACT}

After introducing Gregory of Nyssa's writing style and his addressees, the author presents all the references to God contained in his Work, by means of innumerable quotations.

(415) V, 15, 16-20.

(416) Prol. 5, 1-5.

(417) No hay que humanizar a Dios (cf. p. e. IV, 14, 25-15, 1).

(418) Cf. p. e. XXXV, 91, 3-15. Cf. Srawley, op. cit., p. 100, ad lín. 7, respecto a la apocatástasis y la eternidad de las penas; Kees, op. cit., 141-147, respecto a la muerte como reacción de Dios ante la caída del hombre, y como separación natural del compuesto (cf. R. Kees, Unsterblichkeit und Tod. Zur Spannung zweier anthropoligischer Grundaussagen in Gregors von Nyssa Oratio Catechetica, en H. R. Drobner y Ch Klock, Studien zu Gregor von Nyssa und der christlichen Spätantike (Supplements to Vigiliae Christianae, 12), Leiden 1990, Brill, pp. 211-231). 
Gregory uses the Trinitarian vocabulary scarcely, focusing on God itself. He presents the attributes of this God, who is usually called $\phi v \sigma ı s$ and $\delta v v \alpha \mu ı s$, but he does not develop much of a negative theology. God is known by his works; Christ's divinity by his miracles. God creates and saves out of goodness. The world is good and men were created in state of goodness to participate of the divine goods. The only true evil is the absence of virtue, which comes about from ones' freedom. Man becomes mortal so that his body may be purified from evil through death. Birth and death are not unworthy of God. Christ, by touching death makes it disappear and brings back the union between body and soul. God has ransomed us out of his goodness and wisdom, power and justice (regarding the adversary). The redemption is applied through the imitation of baptism and Eucharistic food that lead us to incorruptibility. The soul, non purified by virtue, will be purified by the fire of the judgment to return to the original state of grace, apocatastasis. Gregory's Christology and redemption are over all descending. A reasonable God is shown on everything. 